\title{
Gold nanoparticles and electromagnetic irradiation in tissue culture systems of bleeding heart: biochemical, physiological, and (cyto) genetic effects
}

\author{
Dariusz Kulus $^{1}$ (D) . Alicja Tymoszuk ${ }^{1}$ (D) - Iwona Jedrzejczyk ${ }^{2}$ (D) · Janusz Winiecki ${ }^{3,4}$ (D)
}

Received: 11 September 2021 / Accepted: 18 January 2022 / Published online: 24 January 2022

(c) The Author(s) 2022

\begin{abstract}
This study aimed to analyze the effect of various mutagens on the in vitro development, physiological activity, acclimatization efficiency, and genetic integrity of Lamprocapnos spectabilis 'Valentine'. Gold nanoparticles (AuNPs), microwaves, and X-rays were used at different doses. The profiles of primary and secondary metabolites and the enzymatic activity in the produced plants were studied. The usefulness of various genetic markers in the detection of mutations in the species was compared. The genome size of $L$. spectabilis was estimated for the first time. It was found that the addition of AuNPs into the culture medium had a positive impact on the in vitro development and multiplication of plants. All of the shoots regenerated adventitious roots, but plants subjected to the longest microwave irradiation $(3 \times 9 \mathrm{~s})$ and the non-treated control had the lowest acclimatization efficiency. Application of mutagens significantly affected the activity and profile of most enzymes and phytochemicals studied, however, the final effect depended on the agent type and dose. Mutations were detected by DAMD, RAPD, and SCoT markers in 7.5\% of plants, but not by ISSRs. Phenotype variation in leaf shape was found in four plants. The genome size of L. spectabilis was found to be very small; about $1281 \mathrm{Mbp}$.
\end{abstract}

\section{Key message}

Gold nanoparticles improve the micropropagation and acclimatization efficiencies in bleeding heart—a species of very small genome size. X-rays, on the other hand, are the most suitable for inducing phenotypical changes. Microwaves are the least useful for both propagation and breeding purposes.

Keywords Genetic variation · Genome size · Hormesis · Lamprocapnos spectabilis (L.) Fukuhara · Micropropagation · Mutation breeding $\cdot$ Spectral fingerprinting

Communicated by T. Winkelmann.

Alicja Tymoszuk

alicja.tymoszuk@pbs.edu.pl

Dariusz Kulus

dkulus@gmail.com

Iwona Jedrzejczyk

jedrzej@pbs.edu.pl

Janusz Winiecki

j.winiecki@cm.umk.pl

1 Laboratory of Ornamental Plants and Vegetable Crops,

Faculty of Agriculture and Biotechnology, Bydgoszcz

University of Science and Technology, Bernardyńska 6 ,

85-029 Bydgoszcz, Poland
2 Laboratory of Molecular Biology and Cytometry, Department of Agricultural Biotechnology, Faculty of Agriculture and Biotechnology, Bydgoszcz University of Science and Technology, Kaliskiego Ave 7, 85-796 Bydgoszcz, Poland

3 Medical Physics Department, Oncology Center, Romanowskiej 2, 85-796 Bydgoszcz, Poland

4 Department of Oncology and Brachytherapy, Collegium Medicum Nicolaus Copernicus University, Gagarina 11, 87-100 Toruń, Poland 


\section{Introduction}

Lamprocapnos spectabilis (L.) Fukuhara is a rhizomatous herbaceous perennial, native to Siberia, northern China, Korea, and Japan (Kamińska et al. 2004; Cho 2018). It is also known as bleeding heart, fallopian buds, lyre flower, or lady-in-a-bath. The species is placed in the Fumarioideae, a subfamily of the poppy family-Papaveraceae (Park et al. 2018). It is the only species in the monotypic genus Lamprocapnos but is still widely referenced under its former name Dicentra spectabilis (L.) Lem. (syn. Fumaria spectabilis L.). Bleeding heart is appreciated in landscape architecture, gardens, and floristry for its decorative leaves and long-viable heart-shaped red, pink, and white flowers, produced in spring. It is also valued in the pharmaceutical and cosmetic markets due to the presence of biologically active isoquinoline alkaloids (Adamski et al. 2020), such as protopine and sanguinarine (Och et al. 2017). Extracts of bleeding heart showed cytotoxic activity against the tested human squamous carcinoma and adenocarcinoma cells (Petruczynik et al. 2019). Therefore, the species is recently focusing the attention of biotechnologists, although its biology and characteristic (e.g. stressrelated physiological reactions) are not fully understood and require more research.

Conventionally, L. spectabilis is propagated vegetatively through softwood cuttings and root division (mainly) or, less frequently, by seeds (Hodges 2012). The viability of seeds is low and they must be sown while fresh, immediately after collection (Deno 1993). Next, the seeds must undergo dormancy through winter to germinate in the spring of the following year. Therefore, there is a long period (almost 1 year) between sowing and germination (Cho et al. 2020). Moreover, the generative method of reproduction fails to retain the characteristics of the mother plant and fulfill the demand of the pharmaceutical market. Cuttings and division provide plants true to the parent plant and a quicker bloom time, however, their yield is limited and climate-dependent (Lema-Rumińska et al. 2019). Hence, it is essential to make novel efforts to establish sufficient plants of L. spectabilis by artificial propagation and breeding methods to meet the elevated market demand.

In vitro tissue culture systems have been successfully utilized for propagation, breeding, preservation, and secondary metabolite production in numerous ornamental and medicinal plant species in the past decades (Rout and Jain 2020). However, in some species, classical plant growth regulators (PGRs), such as benzyl adenine (BA) cause certain morpho-physiological, anatomical, and biochemical disorders that negatively affect the quality of the produced biological material, particularly during acclimatization
(Bidabadi and Jain 2020; Manokari et al. 2021). Bleeding heart can be classified as a species recalcitrant to in vitro propagation as the simultaneous exogenous supply of common auxins and cytokinins into the culture medium, even at low concentrations, results in the abundant secretion of harmful polyphenols, formation of callus, and somaclonal variation occurrence (Kulus et al. 2020). Moreover, the species does not produce efficiently adventitious shoots from leaf, petiole, or internode explants (Kulus and Tymoszuk 2020). Therefore, other factors stimulating the in vitro development of this species should be recognized.

Breeding programs lead to an increase in the number of available cultivars of bleeding heart in the twentieth and twenty-first centuries (Hodges 2012). In vitro techniques were established with the intent to develop commercial cultivars of this species via genetic transformation and regeneration from somatic embryos (Lee and Lee 2003). The site-directed CRISPR/Cas-based technologies also gain increasing interest in the breeding of essential crop plants (Miler et al. 2021). Genetic engineering, however, is a complex, time-absorbing, and expensive method of plant improvement. It is also the subject of public debate. Classical mutation breeding, on the other hand, based on the concept of random mutation induction, is an attractive solution to these problems and it remains still an important method for breeding ornamental plants alongside hybridization (Holme et al. 2019; Datta 2020). The method allows broadening the scope of genetic variation without profoundly changing the whole genome of valued individuals and with no need for sophisticated molecular laboratories equipped with expensive devices, and employees trained in genetic engineering (Jo and Kim 2019). Moreover, it is universal and does not require deep knowledge of genes sequences, structures, and functions (Shelake et al. 2019).

Mutagenic factors used in plant breeding can be classified into two groups: chemical and physical. Among the first group, ethyl methanesulphonate is deployed most often, however, recent studies have shown that nanoparticles (NPs) can be efficacious to induce genotoxic effects in plants, due to their ease of interacting with plant cells (Tymoszuk and Miler 2019; Miler et al. 2021). Silver nanoparticles (AgNPs) are the best-studied in terms of genetic variation induction and catalyzation of reduction-oxidation reactions in a plant cell (Tymoszuk and Kulus 2020). As opposed to AgNPs, fewer studies determining the influence of gold nanoparticles (AuNPs) on plants have been published (Kulus and Tymoszuk 2021). Physical mutagens, such as X- or gammarays, and heavy-ion beams are more eco-friendly as their deployment does not result in chemically harmful waste production. Unfortunately, the accessibility of the devices used for irradiation treatment can be a limiting factor for plant breeders, as those appliances are usually owned by national atomic agencies or medical/scientific institutes (Miler et al. 
2021). Alternatively, a common microwave oven can be an inexpensive and effective source of mutagenic radiation (microwaves; MW), although, to date, this approach has bee used exclusively with Chrysanthemum $\times$ morifolium (Ramat.) Hemsl. by Miler and Kulus (2018).

Recognizing the extent of genetic variation is a key factor for any effective genetic improvement program, micropropagation protocol, and also for any successful hybridization plan to obtain progenies with desirable traits (Adhikari et al. 2020). Due to their simplicity, rapidity, and versatility, genotyping methods based on PCR are now commonly utilized to assess the genetic variation in agricultural, medicinal, and horticultural plants. Single primer amplification reaction (SPAR) methods; such as Randomly Amplified Polymorphic DNA (RAPD) (Williams et al. 1990), Directed Amplification of Minisatellite DNA (DAMD) (Heath et al. 1993), Inter Sequence Simple Repeat (ISSR) (Zietkiewicz et al. 1994), and Start Codon Targeted Polymorphism (SCoT) (Collard and Mackill 2009); are considered powerful tools for studying genetic diversity in plants, especially in those species that have not been well-studied or those for which fingerprinting keys had not been developed. Although each SPAR method has its drawbacks, cumulative data support a comprehensive elucidation of the genetic variability within a species (Nadeem et al. 2017; Adhikari et al. 2020). Flow cytometry (FCM), chemotaxonomy, and phenotyping can be additionally used to obtain a complete view of the stability of plant material. Flow cytometric evaluation of nuclear DNA content is a relatively simple, fast, and lowcost method of verifying genome size stability, requiring only a small amount of biological material (Sliwinska 2018). Changes in metabolic profiles can be studied with the help of chemical fingerprinting. Chemotaxonomy; i.e. the analysis of confirmable differences in the biochemical composition of roots, leaves, flowers, and fruit; is a supplementary method of cultivar identification. Variation in the color of plant organs gave a basis for demonstrating differences across cultivars of various plant species (Lema-Rumińska et al. 2018). Moreover, chemical portrait given by spectral fingerprinting provides information valuable to the pharmaceutical industry.

The literature survey reveals no information of mutation breeding or genome size estimation in bleeding heart. Therefore, the present study was performed (i) to study the impact of chemical (AuNPs) and physical agents (MW and $\mathrm{X}$-rays), applied at various doses, on the in vitro development, micropropagation efficiency, and post-acclimatization quality of bleeding heart 'Valentine'; (ii) to analyze the enzymatic activity and phytochemicals content in the shoots produced; (iii) to asses for the first time the genome size of Lamprocapnos spectabilis using FCM; (iv) to analyze the genetic stability of the greenhouse-grown plants using PCR-based markers; (v) to determine the usefulness of various SPAR marker systems in the detection of genetic variation in bleeding heart.

\section{Materials and methods}

\section{Plant material and in vitro culture conditions}

Single-node shoot fragments of Lamprocapnos spectabilis (L.) Fukuhara 'Valentine', isolated from 8-weekold microcuttings, were vertically inoculated in $350-\mathrm{mL}$ glass jars filled with $40 \mathrm{~mL}$ of MS (Murashige and Skoog 1962) medium augmented with $1.0 \mathrm{mg} \mathrm{L}^{-1}$ kinetin (SigmaAldrich, St. Louis, MO, USA). The medium was additionally supplemented with $30 \mathrm{~g} \mathrm{~L}^{-1}$ of sucrose and solidified with $8.0 \mathrm{~g} \mathrm{~L}^{-1}$ agar (Biocorp, Warsaw, Poland). After adding all the components, the $\mathrm{pH}$ was adjusted to 5.8 before the medium was autoclaved at $121^{\circ} \mathrm{C}$ and $105 \mathrm{kPa}$ for $20 \mathrm{~min}$. Nine explants were placed in each culture jar sealed with a plastic cap. One jar was considered a single repetition.

The cultures were grown at $24 \pm 1{ }^{\circ} \mathrm{C}$ and exposed to a 16 -h photoperiod. Standard cool daylight was provided by TLD54/36 W fluorescent lamps (Koninklijke Philips Electronics N.V., Eindhoven, the Netherlands) with the photosynthetic photon flux density of approximately $35 \mu \mathrm{mol} \mathrm{m}{ }^{2}$ $\mathrm{s}^{-1}$ (Fig. 1A).

\section{Treatment with chemical and physical agents}

Immediately after inoculation in the culture medium, the explants were treated with chemical (AuNPs) or physical agents (MW and X-rays).

\section{AuNPs treatment}

AuNPs, spherical in shape, of $13 \pm 3 \mathrm{~nm}$ diameter and at 50,75 , or $100 \mathrm{ppm}$ concentration, obtained from Nanoparticles Innovation NPIN s.c. (Łódź, Poland), were cold-sterilized through a syringe filter (Minisart ${ }^{\circledR}$ RC 25, pore size $0.20 \mu \mathrm{m}$; Sartorius AG, Göttingen, Germany) and poured onto the culture medium, $2 \mathrm{~mL}$ per one culture jar (Fig. 1B). The detailed characteristics and synthesis protocol of nanoparticles are given in Kulus and Tymoszuk (2021). AuNPs were synthesized using a chemical reduction method. Briefly, an aqueous solution of gold (III) chloride hydrate was heated to the boiling point under reflux and, then, an aqueous solution of sodium citrate was added to the reaction mixture. The solution was heated for 15 min under stirring, and next the colloid was cooled down to room temperature. 
A PPFD Spectrum

Ref.: McCREEs Action Spectrum

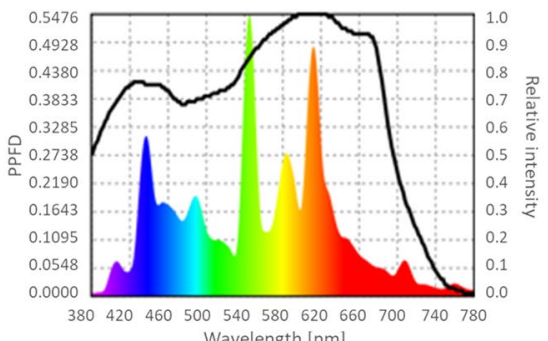

CIE1931 color space

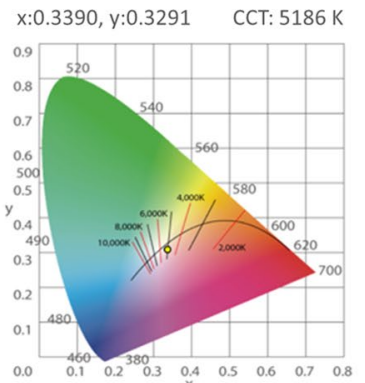

\section{CIE1976}

$u^{\prime}: 0.2162, v^{\prime}: 0.4723 \quad$ CCT: $5186 \mathrm{~K}$

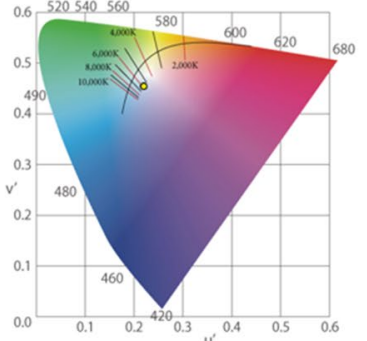

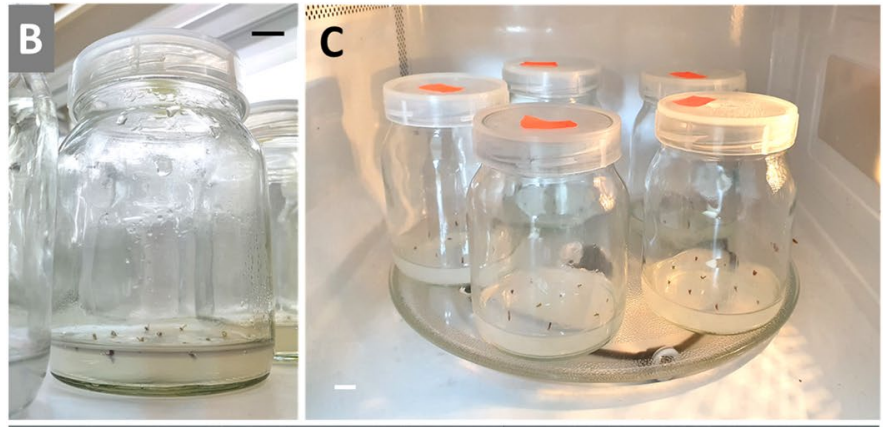
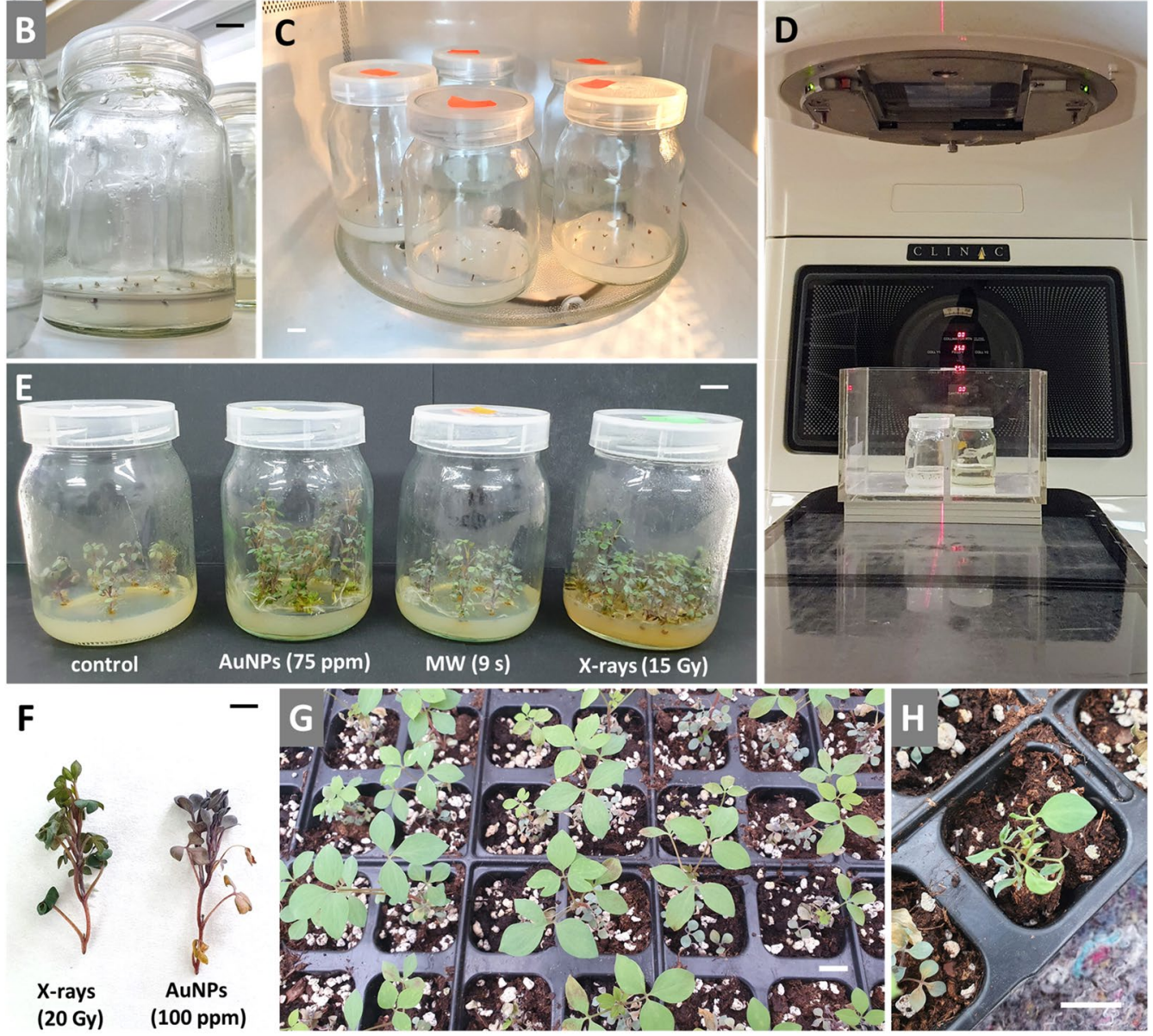

Fig. 1 Application and influence of chemical and physical agents on the growth and development of $L$. spectabilis 'Valentine': A light conditions in the growth room (PPFD photosynthetic photon flux density; measurements taken by spectroradiometer Lighting Passport, AsenseTek, Quebec, Canada); B in vitro culture of nodal explants on the medium containing gold nanoparticles (AuNPs); $\mathbf{C}$ treatment of explants with microwaves (MW); D irradiation of explants with

\section{Microwave treatment}

SAMSUNG MW-73B-S microwave oven with the power of $800 \mathrm{~W} \mathrm{~cm}^{-2}$ and the frequency of $2.45 \mathrm{GHz}$ was used as the source of MW radiation (Fig. 1C). The explants were irradiated with MW for $9 \mathrm{~s}$ in repeated cycles, as

X-rays; $\mathbf{E}$ microshoots produced after 8 weeks of in vitro culture; $\mathbf{F}$ microshoots (12-week-old) from the experimental object treated with 20 Gy of X-rays (with the lowest anthocyanins content) and after application of $100 \mathrm{ppm}$ AuNPs (with the lowest chlorophyll content); $\mathbf{G}$ ex vitro growth of plants in the glasshouse (4th week); $\mathbf{H}$ mutant with an altered leaf shape after irradiation with $10 \mathrm{~Gy}$ of X-rays (4 weeks of ex vitro growth). $B a r=1 \mathrm{~cm}$

following: $1 \times 9 \mathrm{~s}, 2 \times 9 \mathrm{~s}$ (a total of $18 \mathrm{~s})$, and $3 \times 9 \mathrm{~s}(\mathrm{a}$ total of $27 \mathrm{~s}$ ). To maintain a constant room temperature between the successive irradiations, the jars with the explants were cooled in a water bath at the temperature of $10{ }^{\circ} \mathrm{C}$ for $1 \mathrm{~min}$. 


\section{Irradiation with X-rays}

For the time of X-ray treatment, jars with inoculated nodal segments were filled with sterile distilled water so the explants were immersed about $5 \mathrm{~mm}$ below the water surface to avoid the usual confusion arising from a lack of exact dose determination. The objects were irradiated with X-rays of 6MV Nominal Accelerating Potential (NAP) at the Oncology Center in Bydgoszcz, Poland. A conventional medical accelerator Clinac 2300CD Silhouette from Varian Medical Systems (Palo Alto, Santa Clara, CA, USA) was used for the experiment (Fig. 1D). Three total doses were delivered to the explants, i.e. $10 \mathrm{~Gy}$ or $15 \mathrm{~Gy}$ or $20 \mathrm{~Gy}$, with the dose rate $3.39 \mathrm{~Gy} \mathrm{~min}^{-1}\left(300 \mathrm{MU} \mathrm{min}{ }^{-1}\right)$. The source-surface distance (SSD) was $90.8 \mathrm{~cm}$.

Nodes not treated with AuNPs, MW, or X-rays were considered as the control. Each treatment was performed in five repetitions, i.e. with 45 explants in every experimental object. A total of 450 nodal segments were used.

\section{Biometric analysis of in vitro-grown plants}

After 10 weeks of in vitro culture, the share of viable explants, the number of shoots produced, propagation ratio, and spontaneous rooting ability were determined. The propagation ratio was assessed by counting the number of secondary explants (nodal segments) that could be excised from the recovered shoots. Foliar biomass; i.e. the fresh (FW), turgid (TW), and dry (DW) weight of leaves were determined to calculate the relative water content (RTW) in plants based on Dastborhan and Ghassemi-Golezani (2015) with minor modifications. Three young leaves from six plants from each experimental object were used in the analysis with one plant being a single repetition.

\section{Spectral fingerprinting}

The spectral analysis of enzymes and pigments was performed 10 and 11 weeks after culture initiation using 200and 100-mg fresh tissue samples, respectively, in six repetitions and a spectrophotometer SmartSpec PlusTM (BioRad, Hercules, CA, USA).

\section{Determination of enzymatic activity}

Samples taken from in vitro-grown shoots were homogenized in $100 \mathrm{mM}$ phosphate buffer ( $\mathrm{pH}$ 7.4) containing $1 \mathrm{mM}$ EDTA, $1 \mathrm{mM}$ dithiothreitol (DTT), and 2\% polyvinylpyrrolidone (PVP) (all chemicals provided by Chemat, Gdańsk, Poland), according to Homaee and Ehsanpour (2016). The homogenates were centrifuged at $13,000 \times g$ for $20 \mathrm{~min}$ at $4{ }^{\circ} \mathrm{C}$ (Centrifuge MPW-260R, MPW MED INSTRUMENTS, Warsaw, Poland) and supernatants were used to determine the activities of antioxidant enzymes and protein content.

Glutathione reductase (GR; E.C. 1.8.1.7) activity was determined spectrophotometrically by measuring the enzymatic-dependent oxidation of NADPH (Mallebrera et al. 2014). One unit of GR was defined as the amount of enzyme that oxidized $1.0 \mu \mathrm{mol}$ of NADPH in one minute. The guaiacol peroxidase (G-POD; E.C. 1.11.1.7) and ascorbate peroxidase (APX; E.C. 1.11.1.11) activities were monitored based on the polymerization of guaiacol into tetraguaiacol and ascorbate consumption according to Maehly and Chance (1954) and Nakano and Asada (1981), respectively, with modifications described by Nowogórska and Patykowski (2015). Protein content was measured based on the Bradford method (1976) with bovine serum albumin (BSA) as the standard. The spectrophotometric analysis of extracts was performed at specific wavelengths: for proteins at $595 \mathrm{~nm}$, for GR at $340 \mathrm{~nm}$, for G-POD at $470 \mathrm{~nm}$, and for APX at $290 \mathrm{~nm}$. The enzymatic activity U

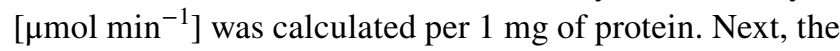
enzyme unit $\mathrm{U}$ was converted to katal, with the assumption that $1 \mathrm{U}=1 / 60 \mu \mathrm{kat}=16.67$ nkat.

\section{Analysis of pigments content}

Chlorophylls and carotenoids (carotenes and xanthophylls) were extracted with the procedure described by Bulda et al. (2008) using a 4:1 mixture of petroleum ether (PE, fraction 60-90) and tetrahydrofuran (THF) and $100 \mathrm{mg}$ of fresh tissue samples. The total flavonoid content of methanol extract was determined by the aluminum chloride method (Brighente et al. 2008). The flavonols content was evaluated with the method described by Kabir et al. (2016). Anthocyanins were extracted using $200 \mathrm{mg}$ leaf samples and methanol containing $1 \% \mathrm{HCl}$, according to the Harborne (1967) method. The same extract was used to analyze the total phenolic and tannin concentrations with the Folin-Ciocalteau reagent, according to the Waterhouse (2001) and Kabir et al. (2016) procedures, respectively. The total flavonoid, flavonol; phenolic; and tannin contents were calculated using quercetin; gallic acid; and tannic acid as the calibration standards $\left(0-400 \mathrm{mg} \mathrm{L}^{-1}\right)$, respectively.

The spectrophotometric analysis of extracts was performed at specific wavelengths $\left(\lambda_{\max }\right)$ : for flavonoids at $420 \mathrm{~nm}$, for flavonols at $440 \mathrm{~nm}$ (maximum absorbance of 3-hydroxy flavone), for carotenoids at 480 and $495 \mathrm{~nm}$ ( $\beta$-carotene and lutein), for anthocyanins (cyanidin-3-glucoside) at $530 \mathrm{~nm}$, for chlorophyll $a$ and $b$ at 645 and $655 \mathrm{~nm}$, and for tannins and phenolics at 725 and $765 \mathrm{~nm}$, respectively. The content of metabolites was calculated per gram of fresh matter. 


\section{Estimation of nuclear DNA content in in vitro-derived plantlets by flow cytometry}

The fresh young leaves of each 12-week-old shoot were sampled to measure the 2C DNA content. The samples for the FCM analysis were prepared according to the procedure described by Rewers et al. (2012), using $1 \mathrm{~mL}$ of nucleiisolation buffer ( $200 \mathrm{mM}$ Tris; $4 \mathrm{mM} \mathrm{MgCl} \mathrm{Mg}_{2} \times 6 \mathrm{H}_{2} \mathrm{O} ; 0.5 \%$ Triton X-100; pH 7.0; Pfosser et al. 1995), supplemented with propidium iodide (PI; $50 \mu \mathrm{g} \mathrm{mL}^{-1}$ ) and ribonuclease A (RNase A; $50 \mu \mathrm{g} \mathrm{mL}^{-1}$ ). Solanum lycopersicum L. 'Stupicke' (2C $=1.96 \mathrm{pg}$; Dolezel et al. 1992) served as an internal standard. For each sample, at least 7000 nuclei were analyzed using a CyFlow SL Green (Partec GmbH, Münster, Germany) flow cytometer, equipped with a high-grade solidstate laser with green light emission at $532 \mathrm{~nm}$, long-pass filter RG 590 E, DM 560 A, as well as with side (SSC) and forward (FSC) scatters. Analyses were performed on 15 biological replicates using linear amplification. Histograms were evaluated using FloMax software (Partec GmbH, Münster, Germany). The coefficient of variation (CV) of the $\mathrm{G}_{0} /$ $\mathrm{G}_{1}$ peak of $L$. spectabilis ranged between 2.56 and $4.09 \%$. Nuclear DNA content was calculated using the linear relationship between the ratio of the $2 \mathrm{C}$ peak positions of bleeding heart/internal standard on the histogram of fluorescence intensities. The $2 \mathrm{C}$ nuclear DNA content in picograms (pg) was transformed into megabase pairs (Mbp) of nucleotides, using the conversion $1 \mathrm{pg}=978 \mathrm{Mbp}$ (Doležel et al. 2003).

\section{In vitro rooting, acclimatization, and ex vitro growth}

Twenty-five to fifty shoots from each experimental combination were rooted and acclimatized. For this purpose, the shoots $3 \mathrm{~cm}$ in length were dissected and transferred on the rooting MS medium containing $2.0 \mathrm{mg} \mathrm{L}^{-1}$ of indole3-acetic acid (IAA) for 21 days.

An additional group of 15 shootlets (three per repetition) representing every experimental combination was grown on the same medium for 6 weeks to collect data on the architecture of their root systems. Root systems were excised from the shoots and scanned (Epson STD4800 scanner, Suwa, Japan) in the transparent polypropylene cuvettes filled with water. Next, root system pictures were analyzed and a mean total length of the roots, a mean root system area, and root diameter, as well as the number of forks and tips, were measured using the imaging software WinRHIZO ${ }^{\mathrm{TM}}$ (Reagen Instruments, Quebec, Canada).

Acclimatization was conducted from October 26 to November 13 in natural light conditions in a glasshouse in five repetitions (with 5-10 plants per repetition). Bleeding hearts were grown individually in plastic trays filled with a mixture of peat and perlite $(2: 1)$, sprayed with water, and covered with perforated foil and geo-cover. The acclimatization effectiveness, i.e. survival rate and quality of plants, was assessed after 42 days. The survival was calculated as the percentage of the number of living plants out of the initial number of acclimatized bleeding hearts. Plants that remained in the healthy form were considered fair quality. Those, which were tiny or had withered leaves were considered poor quality. The quality of shoots with evident signs of growth, i.e. development of new healthy leaves, was considered superb.

\section{Analysis of genetic fidelity}

The genetic fidelity of plants was assessed using DAMD, ISSR, RAPD, and SCoT marker systems, after 6 weeks of ex vitro growth. A total of 80 shoots (eight from each experimental object) were analyzed.

Total genomic DNA was isolated from fresh tissues using a FastPrep-24 5G bead beating grinder and lysis system (MP Biomedicals Irvine, CA, USA) and Genomic Mini AX Plant Spin kit (A\&A Biotechnology, Gdynia, Poland), according to the manufacturer's instruction.

Five primers from each marker system were used in the PCR reaction. PCR was performed in a gradient C1000 Touch thermal cycler with heated cover (Bio-Rad, Hercules, CA, USA) in the $25-\mu \mathrm{L}$ reaction solution. The composition of the reaction solution, PCR profiles, and electrophoretic separation of amplified DNA fragments were described in Adhikari et al. (2020 with modifications) and Kulus (2020). Gel images were recorded using a GelDoc $\mathrm{XR}+$ Gel Photodocumentation System (Bio-Rad, Hercules, CA, USA) UV transilluminator with Image Lab 4.1 software. Molecular weights of the fragments were estimated using a 100-5000 bp DNA molecular marker (Gene Ruler TM Express DNA Ladder, Thermo Fisher Scientific, Waltham, MA, USA).

The banding patterns were recorded as $0-1$ binary matrix, where " 1 " indicates the presence and " 0 " the absence of a given fragment followed by statistical analysis. For every primer tested, the numbers of monomorphic, polymorphic, and specific (unique) bands were counted. Values of Heterozygosity index $(\mathrm{H})$, Polymorphic Information Content (PIC), Effective multiplex ratio (E), Marker Index (MI), Discriminating power (D), and Resolving power (R) were also investigated for every primer and marker system used (Amiryousefi et al. 2018).

\section{Statistical analysis}

The experiment was set up in a completely randomized design. The experimental data were presented as mean \pm standard error (SE). To obtain the normal distribution of the values expressed as a percentage, the Freeman-Tukey double-arcsine transformation was used. The 
results were evaluated by the one-factor analysis of variance (ANOVA) and the Duncan's Multiple Range Test at $p=0.05$ using Statistica 12.0 (Statsoft, Cracow, Poland). Tables with results provide real, untransformed numerical data, with the alphabet indicating the homogeneous groups.

GenAlex 6.5 software package (Peakall and Smouse 2012) was used to count the genetic distance, perform the principal component analysis (PCoA) and run the analysis of molecular variance (AMOVA) with the assumption that the experimental objects (three factors used at three levels, each and the non-treated control) are 10 separate populations. iMEC software was used to calculate the polymorphism indices (Amiryousefi et al. 2018).

\section{Results}

\section{In vitro multiplication and biometric analysis of bleeding heart}

Neither gold nanoparticles nor electromagnetic irradiation affected the viability of the explants, which reached 86-100\% (Table 1). Explants treated with AuNPs produced significantly more shoots (2.2-4.2) than the untreated control (1.1). The propagation ratio was also positively affected by nanoparticles, with 22.9 secondary explants produced after adding 75 ppm AuNPs into the culture medium (Table 1; Fig. 1E). On the other hand, $X$-irradiation had a deleterious effect on spontaneous rooting (24.0-41.4\% of shoots) compared to the control $(80.0 \%)$. No evident callus formation was reported in any experimental object.

Table 1 Influence of chemical and physical agents on the survival and morphogenic response in L. spectabilis 'Valentine' after 10 weeks of in vitro culture

\begin{tabular}{lllll}
\hline Treatment & Survival (\%) & No. of shoots & $\begin{array}{l}\text { Propagation } \\
\text { ratio }\end{array}$ & Rooting (\%) \\
\hline Control & $\begin{array}{c}94.3 \mathrm{a}^{*} \\
\text { Gold nanoparticles }\end{array}$ & $1.1 \pm 0.1 \mathrm{~d}$ & $7.9 \pm 0.5 \mathrm{c}$ & $80.0 \mathrm{ab}$ \\
$50 \mathrm{ppm}$ & $100 \mathrm{a}$ & $2.2 \pm 0.2 \mathrm{bc}$ & $19.8 \pm 0.7 \mathrm{ab}$ & $57.1 \mathrm{bc}$ \\
$75 \mathrm{ppm}$ & $100 \mathrm{a}$ & $4.2 \pm 0.5 \mathrm{a}$ & $22.9 \pm 2.5 \mathrm{a}$ & $74.3 \mathrm{ab}$ \\
$100 \mathrm{ppm}$ & $95.6 \mathrm{a}$ & $2.7 \pm 0.3 \mathrm{~b}$ & $18.6 \pm 1.9 \mathrm{~b}$ & $55.8 \mathrm{bc}$ \\
Microwaves & & & & \\
$9 \mathrm{~s}$ & $100 \mathrm{a}$ & $1.9 \pm 0.7 \mathrm{~b}-\mathrm{d}$ & $8.1 \pm 0.6 \mathrm{c}$ & $78.0 \mathrm{ab}$ \\
$18 \mathrm{~s}$ & $100 \mathrm{a}$ & $2.0 \pm 0.1 \mathrm{~b}-\mathrm{d}$ & $11.2 \pm 0.6 \mathrm{c}$ & $83.3 \mathrm{a}$ \\
$27 \mathrm{~s}$ & $100 \mathrm{a}$ & $1.8 \pm 0.3 \mathrm{~b}-\mathrm{d}$ & $10.7 \pm 1.1 \mathrm{c}$ & $80.5 \mathrm{ab}$ \\
$\mathrm{X}-\mathrm{rays}$ & & & & \\
$10 \mathrm{~Gy}$ & $94.5 \mathrm{a}$ & $1.5 \pm 0.1 \mathrm{~cd}$ & $9.8 \pm 0.5 \mathrm{c}$ & $38.0 \mathrm{~cd}$ \\
$15 \mathrm{~Gy}$ & $86.0 \mathrm{a}$ & $1.7 \pm 0.2 \mathrm{~b}-\mathrm{d}$ & $8.9 \pm 0.4 \mathrm{c}$ & $41.4 \mathrm{~cd}$ \\
$20 \mathrm{~Gy}$ & $100 \mathrm{a}$ & $1.6 \pm 0.1 \mathrm{~b}-\mathrm{d}$ & $9.0 \pm 0.5 \mathrm{c}$ & $24.0 \mathrm{~d}$ \\
\hline
\end{tabular}

*Values are means \pm standard errors (SE), different letters show significant differences using Duncan's test $(P$ value $<0.05)$
Table 2 Influence of chemical and physical agents on the foliar biomass; i.e. mean fresh weight (FW), dry matter content (DW), and relative water content (RCW) in the leaves of $L$. spectabilis 'Valentine' after 10 weeks of in vitro culture

\begin{tabular}{llll}
\hline Treatment & FW $(\mathrm{mg})$ & DW $(\mathrm{mg})$ & RWC $(\%)$ \\
\hline Control & $5.19 \pm 0.55 \mathrm{bc} *$ & $1.27 \pm 0.22 \mathrm{~b}-\mathrm{d}$ & $88.68 \pm 2.06 \mathrm{a}$ \\
\multicolumn{2}{l}{ Gold nanoparticles } & & \\
$50 \mathrm{ppm}$ & $4.75 \pm 0.37 \mathrm{bc}$ & $1.01 \pm 0.10 \mathrm{~d}$ & $90.68 \pm 3.27 \mathrm{a}$ \\
$75 \mathrm{ppm}$ & $3.86 \pm 0.22 \mathrm{c}$ & $1.39 \pm 0.10 \mathrm{~b}-\mathrm{d}$ & $88.88 \pm 2.05 \mathrm{a}$ \\
$100 \mathrm{ppm}$ & $4.58 \pm 0.50 \mathrm{bc}$ & $1.01 \pm 0.07 \mathrm{~d}$ & $85.46 \pm 2.67 \mathrm{a}$ \\
Microwaves & & & \\
$9 \mathrm{~s}$ & $5.22 \pm 0.29 \mathrm{bc}$ & $1.17 \pm 0.05 \mathrm{~cd}$ & $88.42 \pm 1.96 \mathrm{a}$ \\
$18 \mathrm{~s}$ & $4.69 \pm 0.41 \mathrm{bc}$ & $0.98 \pm 0.10 \mathrm{~d}$ & $95.58 \pm 1.27 \mathrm{a}$ \\
$27 \mathrm{~s}$ & $3.68 \pm 0.53 \mathrm{c}$ & $0.96 \pm 0.16 \mathrm{~d}$ & $90.46 \pm 2.51 \mathrm{a}$ \\
X-rays & & & \\
$10 \mathrm{~Gy}$ & $6.46 \pm 0.90 \mathrm{ab}$ & $1.59 \pm 0.22 \mathrm{bc}$ & $91.82 \pm 2.31 \mathrm{a}$ \\
$15 \mathrm{~Gy}$ & $7.49 \pm 0.85 \mathrm{a}$ & $2.27 \pm 0.27 \mathrm{a}$ & $87.87 \pm 1.89 \mathrm{a}$ \\
$20 \mathrm{~Gy}$ & $7.66 \pm 0.81 \mathrm{a}$ & $1.79 \pm 0.22 \mathrm{ab}$ & $93.03 \pm 1.57 \mathrm{a}$ \\
\hline
\end{tabular}

*Values are means $\pm \mathrm{SE}$, different letters show significant differences using Duncan's test $(P$ value $<0.05)$

Irradiation with X-rays, especially $15 \mathrm{~Gy}$ and $20 \mathrm{~Gy}$, increased the fresh and dry weights of leaves compared to the control (Table 2). In contrast, there was no influence of the factors studied on the relative water content in the plants $(85.46-95.58 \%)$.

Table 3 Influence of chemical and physical agents on the activity of ascorbate peroxidase (APX), guaiacol peroxidase (G-POD), and glutathione reductase (GR) in L. spectabilis 'Valentine' after 10 weeks of in vitro culture

\begin{tabular}{llll}
\hline Treatment & APX (nkat) & G-POD (nkat) & GR (nkat) \\
\hline Control & $0.93 \pm 0.05 \mathrm{c}^{*}$ & $0.75 \pm 0.10 \mathrm{e}$ & $159.14 \pm 27.24 \mathrm{~b}-\mathrm{d}$ \\
Gold nanoparticles & & \\
$50 \mathrm{ppm}$ & $1.47 \pm 0.16 \mathrm{bc}$ & $1.00 \pm 0.30 \mathrm{e}$ & $215.22 \pm 25.60 \mathrm{a}-\mathrm{d}$ \\
$75 \mathrm{ppm}$ & $1.38 \pm 0.18 \mathrm{bc}$ & $1.51 \pm 0.18 \mathrm{de}$ & $159.35 \pm 25.72 \mathrm{~b}-\mathrm{d}$ \\
$100 \mathrm{ppm}$ & $1.85 \pm 0.27 \mathrm{a}-\mathrm{c}$ & $2.28 \pm 0.12 \mathrm{~cd}$ & $328.88 \pm 29.81 \mathrm{a}$ \\
Microwaves & & & \\
$9 \mathrm{~s}$ & $1.49 \pm 0.20 \mathrm{bc}$ & $0.92 \pm 0.15 \mathrm{e}$ & $129.69 \pm 33.83 \mathrm{~cd}$ \\
$18 \mathrm{~s}$ & $2.08 \pm 0.29 \mathrm{ab}$ & $2.50 \pm 0.45 \mathrm{bc}$ & $252.23 \pm 79.06 \mathrm{a}-\mathrm{d}$ \\
$27 \mathrm{~s}$ & $2.21 \pm 0.53 \mathrm{ab}$ & $2.06 \pm 0.29 \mathrm{~cd}$ & $279.12 \pm 52.86 \mathrm{a}-\mathrm{c}$ \\
X-rays & & & \\
$10 \mathrm{~Gy}$ & $1.70 \pm 0.25 \mathrm{bc}$ & $2.36 \pm 0.31 \mathrm{bc}$ & $107.05 \pm 13.93 \mathrm{~d}$ \\
$15 \mathrm{~Gy}$ & $1.39 \pm 0.21 \mathrm{bc}$ & $3.10 \pm 0.28 \mathrm{ab}$ & $107.05 \pm 20.45 \mathrm{~d}$ \\
$20 \mathrm{~Gy}$ & $2.68 \pm 0.53 \mathrm{a}$ & $3.54 \pm 0.25 \mathrm{a}$ & $280.85 \pm 66.07 \mathrm{ab}$ \\
\hline
\end{tabular}

*Values are means $\pm \mathrm{SE}$, different letters show significant differences using Duncan's test $(P$ value $<0.05)$ 


\section{Metabolic and physiological activity of bleeding heart}

Plants exposed to 18-27 s microwave treatment and 20 Gy of X-rays had an over two-fold higher APX activity (2.08-2.68 nkat) than the control (0.93 nkat; Table 3). Most of the experimental objects showed higher G-POD activity (2.06-3.54 nkat) compared to the untreated control (0.75 nkat), except for those exposed to 50 and 75 ppm AuNPs, and 9 s microwaving. As for GR, only shoots produced on the medium with the highest AuNPs concentration differed significantly from the control (328.88 and 159.14 nkat, respectively).

The highest content of chlorophyll $a\left(268.7 \mu \mathrm{g} \mathrm{g}^{-1} \mathrm{FW}\right)$, chlorophyll $b$ (284.9 $\left.\mu \mathrm{g} \mathrm{g}^{-1} \mathrm{FW}\right)$, and total chlorophyll (553.6 $\mu \mathrm{g} \mathrm{g}^{-1} \mathrm{FW}$ ) was found in the shoots produced after $18 \mathrm{~s}$ of MW treatment (Table 4). Microshoots produced in the medium with 100 ppm AuNPs, on the other hand, contained less total chlorophyll $\left(217.9 \mu \mathrm{g} \mathrm{g}^{-1} \mathrm{FW}\right)$ than the untreated control (295.4 $\left.\mathrm{\mu g} \mathrm{g}^{-1} \mathrm{FW}\right)$. Nonetheless, none of the experimental objects differed in terms of chlorophyll $a / b$ ratio from the control object. The highest content of carotenes, xanthophylls, and total carotenoids was also found

Table 4 Influence of chemical and physical agents on the content of chlorophyll $a(\mathrm{Cl} a)$, chlorophyll $b(\mathrm{Cl} b)$, total chlorophyll $(\mathrm{Ct})$, carotenes, xanthophylls, and carotenoids in L. spectabilis 'Valentine' after 11 weeks of in vitro culture

\begin{tabular}{|c|c|c|c|c|c|c|c|}
\hline Treatment & $\mathrm{Cl} a\left(\mu \mathrm{g} \mathrm{g}^{-1}\right)$ & $\mathrm{Cl} b\left(\mu \mathrm{g} \mathrm{g}^{-1}\right)$ & $\mathrm{Ct}\left(\mu \mathrm{g} \mathrm{g}^{-1}\right)$ & $\mathrm{Cl} a / b$ & Carotenes $\left(\mu \mathrm{g} \mathrm{g}^{-1}\right)$ & $\begin{array}{l}\text { Xanthophylls ( } \mu \mathrm{g} \\
\mathrm{g}^{-1} \text { ) }\end{array}$ & Carotenoids $\left(\mu \mathrm{g} \mathrm{g}^{-1}\right)$ \\
\hline Control & $167.5 \pm 11.9 \mathrm{c}-\mathrm{e}^{*}$ & $127.9 \pm 10.7 \mathrm{~b}-\mathrm{d}$ & $295.4 \pm 8.0 \mathrm{bc}$ & $1.39 \pm 0.2 \mathrm{a}-\mathrm{d}$ & $43.8 \pm 7.8 \mathrm{a}$ & $66.5 \pm 10.6 \mathrm{bc}$ & $110.3 \pm 7.6 \mathrm{~b}$ \\
\hline \multicolumn{8}{|c|}{ Gold nanoparticles } \\
\hline 50 ppm & $148.5 \pm 9.6 \mathrm{de}$ & $170.0 \pm 13.3 \mathrm{~b}$ & $318.5 \pm 22.5 \mathrm{bc}$ & $0.88 \pm 0.0 \mathrm{~d}$ & $31.5 \pm 5.4 \mathrm{ab}$ & $85.9 \pm 5.2 \mathrm{bc}$ & $117.4 \pm 7.6 \mathrm{~b}$ \\
\hline 75 ppm & $142.7 \pm 13.9 \mathrm{de}$ & $143.1 \pm 11.9 \mathrm{bc}$ & $285.9 \pm 9.9 \mathrm{~cd}$ & $1.07 \pm 0.2 b-d$ & $8.3 \pm 1.2 \mathrm{c}$ & $84.8 \pm 7.6 \mathrm{bc}$ & $93.0 \pm 9.5 \mathrm{~b}$ \\
\hline $100 \mathrm{ppm}$ & $123.0 \pm 9.3 \mathrm{e}$ & $94.8 \pm 10.8 \mathrm{~d}$ & $217.9 \pm 7.1 \mathrm{~d}$ & $1.30 \pm 0.3 \mathrm{a}-\mathrm{d}$ & $27.4 \pm 7.3 \mathrm{a}-\mathrm{c}$ & $62.3 \pm 8.8 \mathrm{c}$ & $89.7 \pm 8.0 \mathrm{~b}$ \\
\hline \multicolumn{8}{|l|}{ Microwaves } \\
\hline $9 \mathrm{~s}$ & $219.2 \pm 45.1 \mathrm{a}-\mathrm{c}$ & $155.9 \pm 26.6 \mathrm{bc}$ & $375.0 \pm 60.5 \mathrm{~b}$ & $1.46 \pm 0.3 \mathrm{a}-\mathrm{d}$ & $23.8 \pm 8.8 \mathrm{a}-\mathrm{c}$ & $89.3 \pm 11.8 \mathrm{bc}$ & $113.1 \pm 16.5 b$ \\
\hline $18 \mathrm{~s}$ & $268.7 \pm 12.3 \mathrm{a}$ & $284.9 \pm 21.6 \mathrm{a}$ & $553.6 \pm 15.6 \mathrm{a}$ & $0.99 \pm 0.1 \mathrm{~cd}$ & $41.2 \pm 6.8 \mathrm{a}$ & $175.6 \pm 11.1 \mathrm{a}$ & $216.8 \pm 15.5 \mathrm{a}$ \\
\hline $27 \mathrm{~s}$ & $156.9 \pm 14.4 \mathrm{c}-\mathrm{e}$ & $154.5 \pm 6.5 \mathrm{bc}$ & $311.4 \pm 19.2 \mathrm{bc}$ & $1.01 \pm 0.1 \mathrm{~b}-\mathrm{d}$ & $12.1 \pm 3.8 \mathrm{bc}$ & $91.6 \pm 4.5 \mathrm{~b}$ & $103.7 \pm 3.7 b$ \\
\hline \multicolumn{8}{|l|}{ X-rays } \\
\hline $10 \mathrm{~Gy}$ & $203.8 \pm 4.8 \mathrm{~b}-\mathrm{d}$ & $134.6 \pm 11.8 \mathrm{~b}-\mathrm{d}$ & $338.4 \pm 8.5 \mathrm{bc}$ & $1.58 \pm 0.2 \mathrm{a}-\mathrm{c}$ & $26.5 \pm 3.8 \mathrm{a}-\mathrm{c}$ & $75.7 \pm 9.4 \mathrm{bc}$ & $102.2 \pm 10.7 \mathrm{~b}$ \\
\hline $15 \mathrm{~Gy}$ & $184.0 \pm 26.4 \mathrm{~b}-\mathrm{e}$ & $114.9 \pm 3.5 \mathrm{~cd}$ & $298.9 \pm 23.8 \mathrm{bc}$ & $1.64 \pm 0.3 \mathrm{ab}$ & $27.5 \pm 7.0 \mathrm{a}-\mathrm{c}$ & $83.2 \pm 9.8 \mathrm{bc}$ & $110.7 \pm 5.2 b$ \\
\hline $20 \mathrm{~Gy}$ & $241.7 \pm 21.1 \mathrm{ab}$ & $131.2 \pm 9.3 \mathrm{~b}-\mathrm{d}$ & $373.0 \pm 29.5 \mathrm{~b}$ & $1.83 \pm 0.1 \mathrm{a}$ & $13.5 \pm 3.5 \mathrm{bc}$ & $94.9 \pm 6.6 b$ & $108.4 \pm 6.2 b$ \\
\hline
\end{tabular}

*Values are means $\pm \mathrm{SE}$, different letters show significant differences using Duncan's test $(P$ value $<0.05)$

Table 5 Influence of chemical and physical agents on the content of total polyphenols (TPC), flavonoids, flavonols, anthocyanins, and tannins in L. spectabilis 'Valentine' after 11 weeks of in vitro culture

\begin{tabular}{|c|c|c|c|c|c|}
\hline Treatment & $\mathrm{TPC}\left(\mathrm{mg} \mathrm{g}^{-1}\right)$ & Flavonoids $\left(\mathrm{mg} \mathrm{g}^{-1}\right)$ & Flavonols $\left(\mathrm{mg} \mathrm{g}^{-1}\right)$ & Anthocyanins $\left(\mu \mathrm{g} \mathrm{g}^{-1}\right)$ & Tannins $\left(\mu \mathrm{g} \mathrm{g}^{-1}\right)$ \\
\hline Control & $5.46 \pm 0.11 \mathrm{c}^{*}$ & $2.54 \pm 0.13 \mathrm{a}$ & $1.33 \pm 0.09 \mathrm{a}$ & $121.9 \pm 5.0 \mathrm{ab}$ & $3.75 \pm 0.04 \mathrm{e}$ \\
\hline \multicolumn{6}{|c|}{ Gold nanoparticles } \\
\hline $50 \mathrm{ppm}$ & $6.68 \pm 0.23 a b$ & $2.39 \pm 0.03 \mathrm{a}$ & $1.22 \pm 0.02 \mathrm{a}$ & $118.3 \pm 4.3 \mathrm{ab}$ & $4.01 \pm 0.06 \mathrm{ab}$ \\
\hline $75 \mathrm{ppm}$ & $6.62 \pm 0.24 \mathrm{ab}$ & $2.44 \pm 0.07 \mathrm{a}$ & $1.22 \pm 0.03 \mathrm{a}$ & $129.7 \pm 2.5 \mathrm{a}$ & $4.00 \pm 0.06 \mathrm{ab}$ \\
\hline 100 ppm & $6.23 \pm 0.18 \mathrm{ab}$ & $2.57 \pm 0.12 \mathrm{a}$ & $1.32 \pm 0.02 \mathrm{a}$ & $113.9 \pm 1.9 \mathrm{a}-\mathrm{c}$ & $4.03 \pm 0.02 \mathrm{a}$ \\
\hline \multicolumn{6}{|l|}{ Microwaves } \\
\hline $9 \mathrm{~s}$ & $6.48 \pm 0.21 \mathrm{ab}$ & $2.48 \pm 0.10 \mathrm{a}$ & $1.28 \pm 0.10 \mathrm{a}$ & $120.4 \pm 9.1 \mathrm{ab}$ & $3.87 \pm 0.02 b-e$ \\
\hline $18 \mathrm{~s}$ & $6.53 \pm 0.39 a b$ & $2.56 \pm 0.08 \mathrm{a}$ & $1.39 \pm 0.07 \mathrm{a}$ & $118.6 \pm 2.0 \mathrm{ab}$ & $3.87 \pm 0.05$ b-e \\
\hline $27 \mathrm{~s}$ & $6.41 \pm 0.04 \mathrm{ab}$ & $2.32 \pm 0.07 \mathrm{a}$ & $1.22 \pm 0.02 \mathrm{a}$ & $114.6 \pm 4.2 \mathrm{a}-\mathrm{c}$ & $3.93 \pm 0.01 \mathrm{a}-\mathrm{d}$ \\
\hline \multicolumn{6}{|l|}{ X-rays } \\
\hline $10 \mathrm{~Gy}$ & $6.96 \pm 0.38 \mathrm{a}$ & $2.37 \pm 0.10 \mathrm{a}$ & $1.21 \pm 0.07 \mathrm{a}$ & $127.6 \pm 1.6 \mathrm{ab}$ & $3.98 \pm 0.05 \mathrm{a}-\mathrm{c}$ \\
\hline 15 Gy & $6.86 \pm 0.08 \mathrm{ab}$ & $2.47 \pm 0.09 \mathrm{a}$ & $1.35 \pm 0.05 \mathrm{a}$ & $106.5 \pm 9.8 \mathrm{bc}$ & $3.84 \pm 0.03 \mathrm{de}$ \\
\hline $20 \mathrm{~Gy}$ & $6.14 \pm 0.15 b$ & $2.41 \pm 0.09 \mathrm{a}$ & $1.40 \pm 0.03 \mathrm{a}$ & $97.6 \pm 4.2 \mathrm{c}$ & $3.85 \pm 0.05 \mathrm{c}-\mathrm{e}$ \\
\hline
\end{tabular}

*Values are means \pm SE, different letters show significant differences using Duncan's test $(P$ value $<0.05)$ 
after $18 \mathrm{~s}$ microwave treatment and in the control bleeding hearts in the case of carotenes (Table 4). On the other hand, there was no impact of the tested factors on the ratio of total chlorophyll to carotenoids (data not shown).

All shoots produced from explants treated with AuNPs or electromagnetic irradiation contained more polyphenols (6.14-6.96 $\left.\mathrm{mg} \mathrm{g}^{-1} \mathrm{FW}\right)$ than the untreated control $(5.46 \mathrm{mg}$ $\mathrm{g}^{-1} \mathrm{FW}$; Table 5). In contrast, there was no influence of the tested agents on the content of flavonoids $\left(2.32-2.57 \mathrm{mg} \mathrm{g}^{-1}\right.$ $\mathrm{FW}$ ) and flavonols in bleeding heart (1.22-1.40 $\left.\mathrm{mg} \mathrm{g}^{-1} \mathrm{FW}\right)$. None of the analyzed shoots contained more anthocyanins than the control, however, bleeding hearts irradiated with 20 Gy of X-rays contained markedly less pigments of this group (Table 5), resulting in an evident phenotype change (Fig. 1F). As for tannins, an increase in their concentration was detected in the experimental objects treated with AuNPs, regardless of nanoparticles concentration, and after treatment with the highest and lowest dose of microwaves and X-rays, respectively (Table 5).

\section{Estimation of nuclear DNA content in in vitro-derived plantlets by flow cytometry}

The genome size of $L$. spectabilis was found to be very small; approximately $1281 \mathrm{Mbp}(1.268-1.351 \mathrm{pg} / 2 \mathrm{C}$; mean $1.314 \mathrm{pg} / 2 \mathrm{C}$ ). No changes in the ploidy level were reported in any of the 150 plants analyzed, regardless of treatment. However, a total of four plants (from $50 \mathrm{ppm}$ AuNPs, 27 s MW, $10 \mathrm{~Gy}$, and $20 \mathrm{~Gy}$ X-rays treatments) contained a markedly lower DNA content than the remaining specimens from those experimental combinations. Moreover, one specimen after $10 \mathrm{~Gy} \mathrm{X}$-irradiation contained significantly more DNA in its nuclei (Fig. 2). Plants treated with 20 Gy X-rays had the highest range of nuclear DNA content.

\section{In vitro rooting, acclimatization, and ex vitro growth}

All shoots regenerated adventitious roots on the IAA-supplemented rooting medium. The longest roots $(6.0 \mathrm{~cm})$, significantly different from the control $(3.8 \mathrm{~cm})$, were found in the experimental object with $100 \mathrm{ppm}$ AuNPs in the culture medium (Table 6). On the other hand, plants treated with 15 and 20 Gy regenerated the shortest root systems $(1.7-1.9 \mathrm{~cm})$. None of the agents tested increased the area of the root system, but plants produced after X-irradiation, regardless of the dose, had a smaller root area (0.40-0.56 $\mathrm{cm}^{2}$ ) and volume (6.7-10.5 $\left.\mathrm{mm}^{3}\right)$ compared to the control $\left(0.91 \mathrm{~cm}^{2} ; 18.9 \mathrm{~mm}^{3}\right)$. On the other hand, the application of $100 \mathrm{ppm}$ AuNPs resulted in the smallest root diameter (Table 6). The highest (22.4) and lowest (5.3) numbers of forks were found in the root systems of plants treated with $100 \mathrm{ppm}$ AuNPs and 20 Gy of X-rays, respectively. There was no difference in the number of tips between the untreated control and any other experimental object (Table 6).

A complete $100 \%$ survival of shoots was reported after the 2-week acclimatization, regardless of treatment (Fig. 1G). However, in the following weeks, some of the
Fig. 2 Nuclear DNA content obtained after flow cytometric analysis of $L$. spectabilis 'Valentine' plants after various treatments with chemical and physical agents. Individuals marked with an asterisk have a significantly higher/lower nuclear DNA content than other plants within the same experimental object

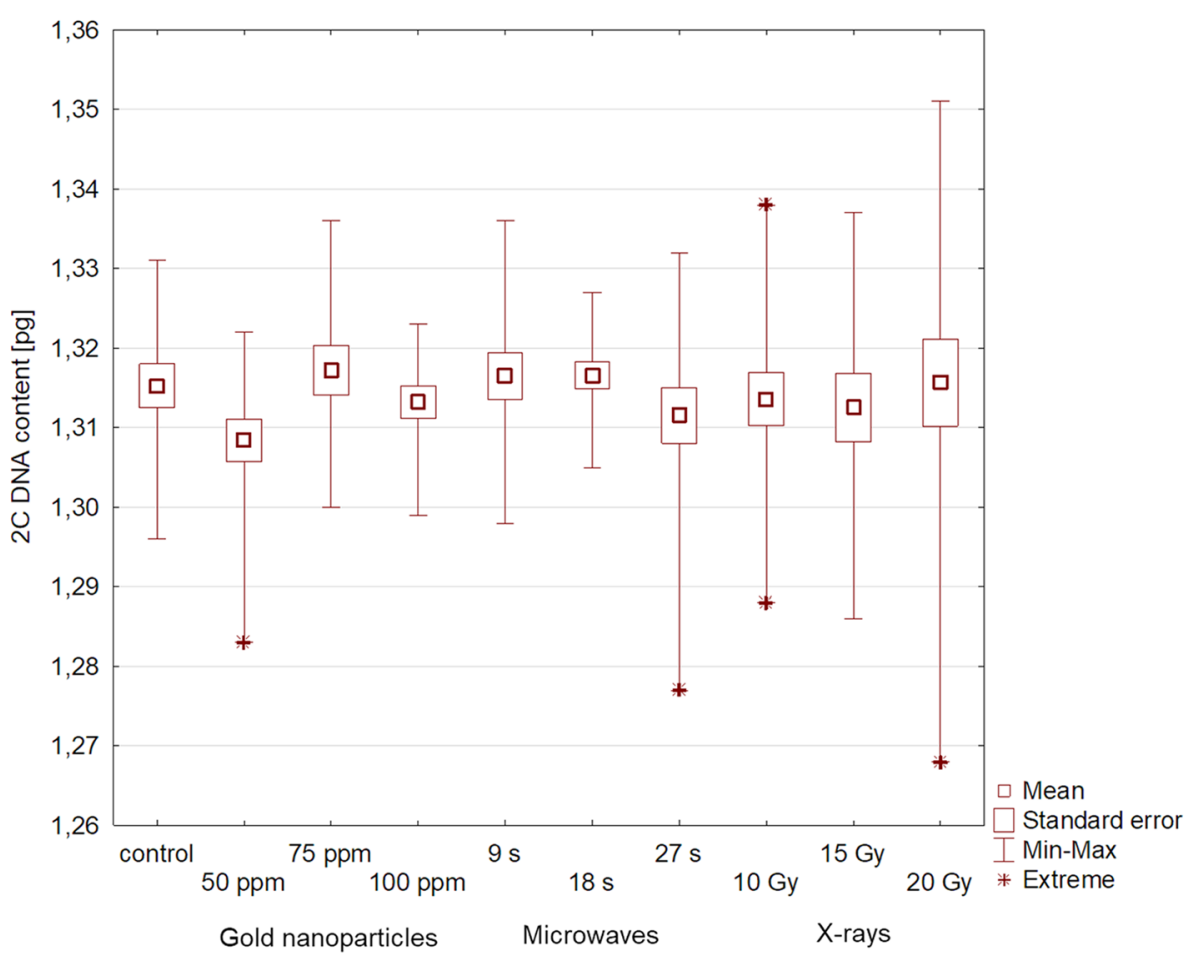


Table 6 Influence of chemical and physical agents on the root system architecture in L. spectabilis 'Valentine' after 6 weeks of in vitro rooting culture on the MS medium with $2.0 \mathrm{mg} \mathrm{L}^{-1}$ IAA

\begin{tabular}{|c|c|c|c|c|c|c|}
\hline Treatment & Total length (cm) & Area $\left(\mathrm{cm}^{2}\right)$ & Volume $\left(\mathrm{mm}^{3}\right)$ & Diameter (mm) & No. of forks & No. of tips \\
\hline Control & $3.8 \pm 0.6 \mathrm{bc}^{*}$ & $0.91 \pm 0.11 \mathrm{a}$ & $18.9 \pm 1.3 \mathrm{a}$ & $0.87 \pm 0.05 \mathrm{a}$ & $13.1 \pm 2.3 \mathrm{~b}-\mathrm{d}$ & $18.0 \pm 4.7 \mathrm{a}-\mathrm{d}$ \\
\hline \multicolumn{7}{|c|}{ Gold nanoparticles } \\
\hline $50 \mathrm{ppm}$ & $4.6 \pm 0.5 \mathrm{ab}$ & $0.89 \pm 0.08 \mathrm{a}$ & $14.6 \pm 1.3 \mathrm{ab}$ & $0.69 \pm 0.02 \mathrm{bc}$ & $17.5 \pm 2.9 \mathrm{ab}$ & $25.5 \pm 1.6 \mathrm{ab}$ \\
\hline $75 \mathrm{ppm}$ & $4.2 \pm 0.8 \mathrm{bc}$ & $0.90 \pm 0.11 \mathrm{a}$ & $16.2 \pm 1.6 \mathrm{a}$ & $0.77 \pm 0.07 \mathrm{ab}$ & $15.9 \pm 2.6 \mathrm{a}-\mathrm{c}$ & $20.9 \pm 3.2 \mathrm{a}-\mathrm{c}$ \\
\hline $100 \mathrm{ppm}$ & $6.0 \pm 0.9 \mathrm{a}$ & $1.04 \pm 0.10 \mathrm{a}$ & $14.9 \pm 1.5 \mathrm{ab}$ & $0.59 \pm 0.04 \mathrm{c}$ & $22.4 \pm 3.4 \mathrm{a}$ & $27.1 \pm 4.1 \mathrm{a}$ \\
\hline \multicolumn{7}{|l|}{ Microwaves } \\
\hline $9 \mathrm{~s}$ & $3.6 \pm 0.5 b-d$ & $0.77 \pm 0.07 \mathrm{ab}$ & $13.7 \pm 1.0 \mathrm{a}-\mathrm{c}$ & $0.72 \pm 0.05 \mathrm{a}-\mathrm{c}$ & $13.0 \pm 1.7 \mathrm{~b}-\mathrm{d}$ & $16.5 \pm 2.9 \mathrm{~b}-\mathrm{c}$ \\
\hline $18 \mathrm{~s}$ & $3.0 \pm 0.6 \mathrm{~b}-\mathrm{e}$ & $0.77 \pm 0.13 \mathrm{ab}$ & $16.9 \pm 2.7 \mathrm{a}$ & $0.89 \pm 0.03 \mathrm{a}$ & $11.1 \pm 2.2 \mathrm{~b}-\mathrm{e}$ & $11.4 \pm 2.4 \mathrm{~cd}$ \\
\hline $27 \mathrm{~s}$ & $3.4 \pm 0.6 \mathrm{~b}-\mathrm{e}$ & $0.79 \pm 0.11 \mathrm{ab}$ & $16.3 \pm 2.2 \mathrm{a}$ & $0.86 \pm 0.08 \mathrm{ab}$ & $11.3 \pm 1.8 \mathrm{~b}-\mathrm{e}$ & $15.5 \pm 2.2 b-c$ \\
\hline \multicolumn{7}{|l|}{ X-rays } \\
\hline $10 \mathrm{~Gy}$ & $2.5 \pm 0.3 \mathrm{c}-\mathrm{e}$ & $0.56 \pm 0.06 \mathrm{bc}$ & $10.5 \pm 1.2 \mathrm{~b}-\mathrm{d}$ & $0.76 \pm 0.05 \mathrm{a}-\mathrm{c}$ & $9.8 \pm 2.2 \mathrm{c}-\mathrm{e}$ & $14.9 \pm 2.9 \mathrm{~cd}$ \\
\hline $15 \mathrm{~Gy}$ & $1.9 \pm 0.5 \mathrm{de}$ & $0.40 \pm 0.09 \mathrm{c}$ & $6.7 \pm 1.1 \mathrm{e}$ & $0.75 \pm 0.07 \mathrm{a}-\mathrm{c}$ & $5.8 \pm 2.1 \mathrm{de}$ & $14.7 \pm 5.1 \mathrm{~cd}$ \\
\hline $20 \mathrm{~Gy}$ & $1.7 \pm 0.2 \mathrm{e}$ & $0.44 \pm 0.06 \mathrm{c}$ & $9.1 \pm 1.4 \mathrm{de}$ & $0.88 \pm 0.03 \mathrm{a}$ & $5.3 \pm 0.6 \mathrm{e}$ & $8.9 \pm 1.8 \mathrm{~d}$ \\
\hline
\end{tabular}

*Values are means $\pm \mathrm{SE}$, different letters show significant differences using Duncan's test $(P$ value $<0.05)$

plants eventually died. Plantlets from the control object and after $27 \mathrm{~s}$ treatment with microwaves had significantly lower survivability (86-88\%) after 6 weeks of ex vitro growth than those from the remaining experimental combinations (96-100\%) (Fig. 3A).

Over $80 \%$ of acclimatized plants treated with $75 \mathrm{ppm}$ AuNPs, 18 s of microwaves, or 20 Gy of X-rays were of superb quality, with several new leaves developed. Only in the control object, the share of plants of the highest quality was below 50\% (Fig. 3B). Most of the bleeding hearts did not differ phenotypically from the control (Fig. 1G). However, four plants (one after 75 ppm AuNPs treatment, two after $10 \mathrm{~Gy} \mathrm{X}$-rays irradiation, and one from the $20 \mathrm{~Gy}$ $\mathrm{X}$-rays combination) were markedly different with an altered, more irregular shape of leaves (Fig. 1H).

\section{Analysis of genetic fidelity}

A total of 12,394 scorable bands were detected by five DAMD, four ISSR, five RAPD, and five SCoT primers in 80 plants (Table 7). The size of bands ranged from 152.9 to $2976.8 \mathrm{bp}$. One ISSR primer (I-3) failed to generated unambiguous amplicons; therefore, it was not included in the study. Among the molecular marker systems tested, DAMDs generated most polymorphisms: a total of $52.5 \%$ loci were polymorphic in six specimens (i.e. $7.5 \%$ of all plants analyzed). Primers D-1 and D-3 generated the highest number of bands ( 17 per sample). The latter one was also the most effective in screening for variation (six distinguished genotypes). On the other hand, primer D-4 produced only six amplicons per sample. This was also the only DAMD primer that did not detect polymorphisms in the present study. Specific loci were the least numerous (2.0 per primer), followed by polymorphic (4.4) and monomorphic ones (5.8). As for RAPD analysis, three primers (R-3, R-4, and R-5) detected polymorphic and specific bands in five plants $(6.25 \%$ of all plants tested). Similarly, four SCoT primers (all except for S-1) generated polymorphic amplicons in five specimens. No polymorphisms were detected by ISSRs. This marker system detected also the lowest mean number of bands ( 480 per primer). An example visualization of PCR products is shown in Fig. 4. No polymorphisms were found in the control plants.

Among the three marker systems, which detected polymorphic bands, the highest mean H, PIC, and MI values were reported with DAMDs (Table 8). Those markers also had the highest mean discriminating power (0.492), followed by RAPD (0.402) and SCoT (0.286). On the other hand, the highest resolving power was found with RAPDs (0.360).

According to the PCoA analysis, three genotypes obtained as a result of treatment with $20 \mathrm{~Gy} \mathrm{X}$-rays (two genotypes) and 100 ppm AuNPs (one genotype) were the most distinct from the predominant control, based on the data provided by three marker systems (Fig. 5). The genotype obtained after $75 \mathrm{ppm}$ AuNPs treatment was also distant from the control according to RAPD and SCoT markers, although not so much according to DAMDs. Similarly, various positioning of the genotype created after MW irradiation for $27 \mathrm{~s}$ was found with DAMD and SCoT markers. A relatively small distance between the control group and genotype obtained after 15 Gy X-rays treatment was detected by DAMDs.

The AMOVA analysis; based on DAMD, RAPD, and SCoT markers; confirmed a significant influence of the experimental treatments on the occurrence of interspecific genetic variation in bleeding heart 'Valentine' (data not shown). The comparison of the efficacy of various marker 
Fig. 3 Influence of chemical and physical agents on the acclimatization efficiency (A) and quality of plants after 6 weeks of ex vitro growth $(\mathbf{B})$
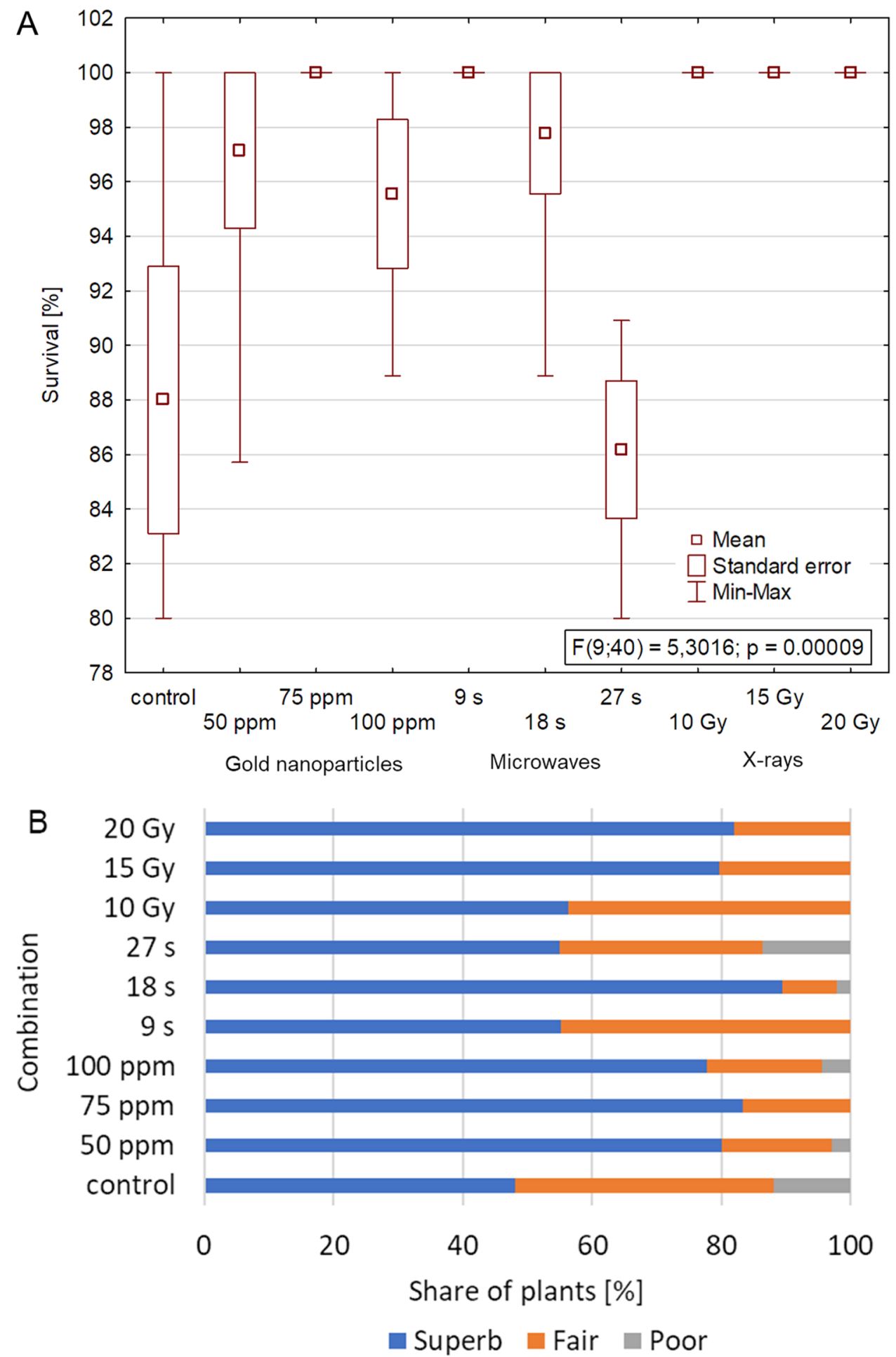

types is shown in Table 9. Noticeably, all plants which showed phenotype alternations were also distinguished by SPAR and/or FCM analyses (mutants M2, M5, M6, M8). However, five genotypes that were distinguished by (cyto) genetic markers did not have evident phenotype changes.

\section{Discussion}

The development of efficient in vitro culture systems is imperative for the large-scale production, acquisition 


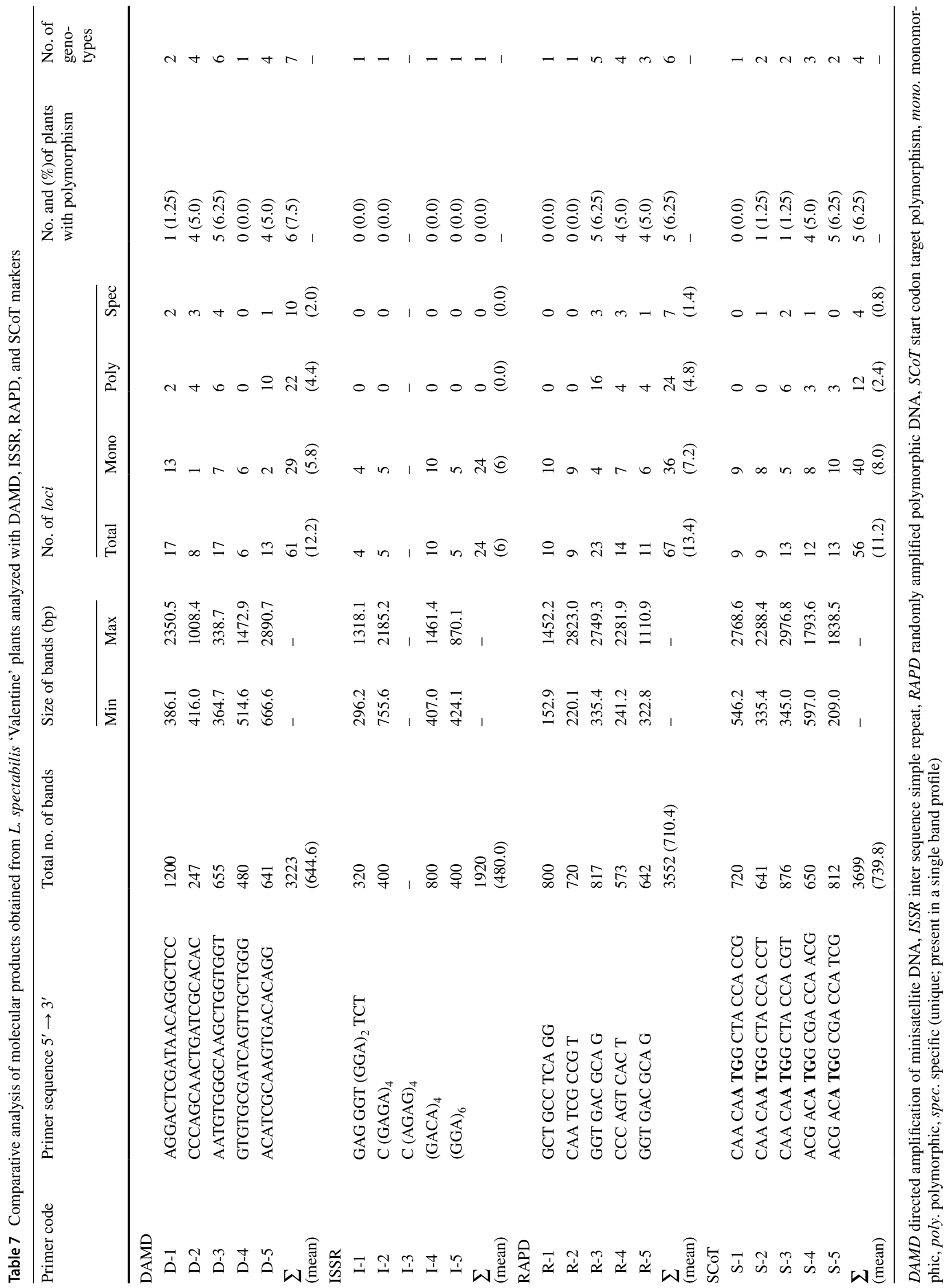


Fig. 4 Example DAMD band profiles of $L$. spectabilis

'Valentine' received as a result of electrophoresis of the DNA amplification products obtained with primer D-1. Outermost lanes (wm) are DNA bp weight markers, while inner lines represent plants treated with gold nanoparticles (AuNPs), microwaves (MW), X-rays, and the non-treated control. Arrows indicate polymorphic genotypes

Table 8 Values of

Heterozygosity index $(\mathrm{H})$,

Polymorphic Information

Content (PIC), Effective

multiplex ratio (E), Marker

Index (MI), Discriminating power (D), and Resolving power

(R) of the marker systems used in the study

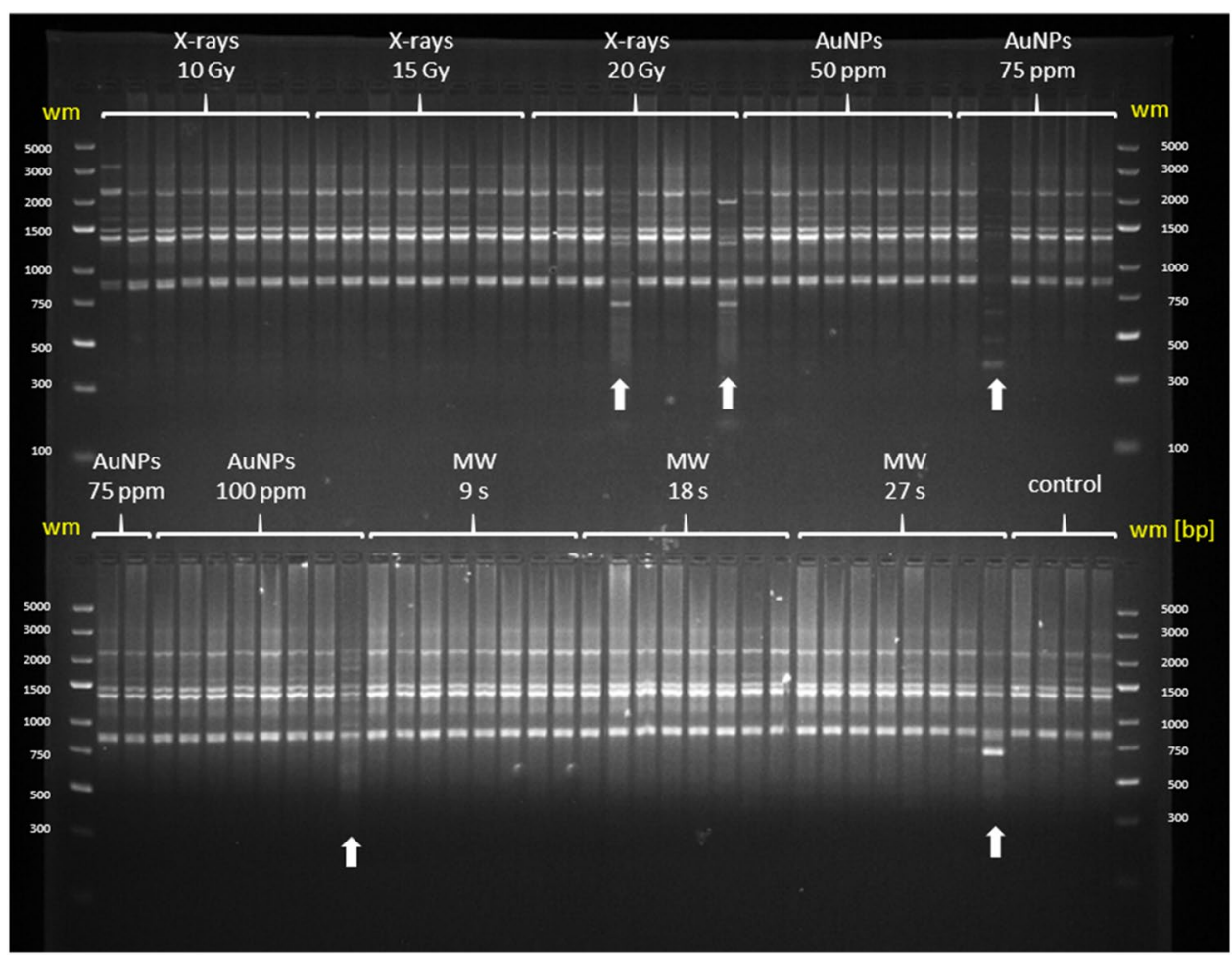

\begin{tabular}{|c|c|c|c|c|c|c|}
\hline Primer & $\mathrm{H}$ & PIC & $\mathrm{E}$ & MI & D & $\mathrm{R}$ \\
\hline \multicolumn{7}{|l|}{ DAMD } \\
\hline D-1 & 0.208 & 0.186 & 15.00 & 0.0023 & 0.222 & 0.100 \\
\hline D-2 & 0.474 & 0.362 & 3.088 & 0.0023 & 0.851 & 0.275 \\
\hline D-3 & 0.499 & 0.375 & 8.188 & 0.0030 & 0.768 & 0.475 \\
\hline D-4 & 0 & 0 & 0 & 0 & 0 & 0 \\
\hline D-5 & 0.473 & 0.361 & 8.012 & 0.0036 & 0.620 & 0.625 \\
\hline Mean & 0.331 & 0.257 & 6.858 & 0.0022 & 0.492 & 0.295 \\
\hline \multicolumn{7}{|l|}{ ISSR } \\
\hline Mean & 0 & 0 & 0 & 0 & 0 & 0 \\
\hline \multicolumn{7}{|l|}{ RAPD } \\
\hline R-1 & 0 & 0 & 0 & 0 & 0 & 0 \\
\hline R-2 & 0 & 0 & 0 & 0 & 0 & 0 \\
\hline R-3 & 0.494 & 0.372 & 10.21 & 0.003 & 0.803 & 1.125 \\
\hline R-4 & 0.500 & 0.375 & 7.163 & 0.003 & 0.738 & 0.325 \\
\hline R-5 & 0.395 & 0.317 & 8.025 & 0.004 & 0.468 & 0.350 \\
\hline Mean & 0.278 & 0.213 & 5.080 & 0.002 & 0.402 & 0.360 \\
\hline \multicolumn{7}{|l|}{ SCoT } \\
\hline S-1 & 0 & 0 & 0 & 0 & 0 & 0 \\
\hline S-2 & 0.195 & 0.176 & 8.013 & 0.002 & 0.208 & 0.025 \\
\hline S-3 & 0.266 & 0.230 & 10.95 & 0.003 & 0.291 & 0.200 \\
\hline S-4 & 0.437 & 0.342 & 8.125 & 0.004 & 0.542 & 0.250 \\
\hline S-5 & 0.342 & 0.284 & 10.15 & 0.003 & 0.391 & 0.300 \\
\hline Mean & 0.248 & 0.206 & 7.448 & 0.002 & 0.286 & 0.155 \\
\hline
\end{tabular}

$D A M D$ directed amplification of minisatellite DNA, ISSR inter sequence simple repeat, RAPD randomly amplified polymorphic DNA, SCoT start codon target polymorphism 

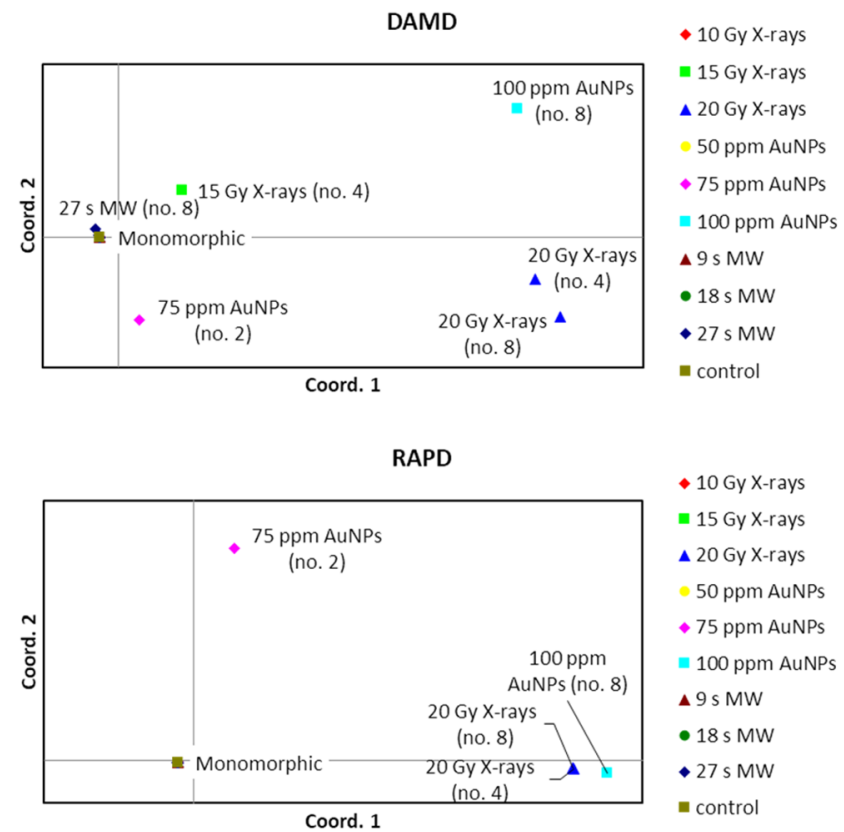

- 10 Gy X-rays

15 Gy X-rays

A 20 Gy X-rays

50 ppm AuNPs

$\checkmark 75$ ppm AuNPs

$\because 100$ ppm AuNPs

$\triangle 9 \mathrm{~s}$ MW

- $18 \mathrm{~s} \mathrm{MW}$

$\bullet 27$ s MW

control

Fig. 5 Graphs of principal coordinates analysis (PCoA) of L. spectabilis 'Valentine' plants after various treatments; based on Directed Amplification of Minisatellite DNA (DAMD), Inter Sequence Simple
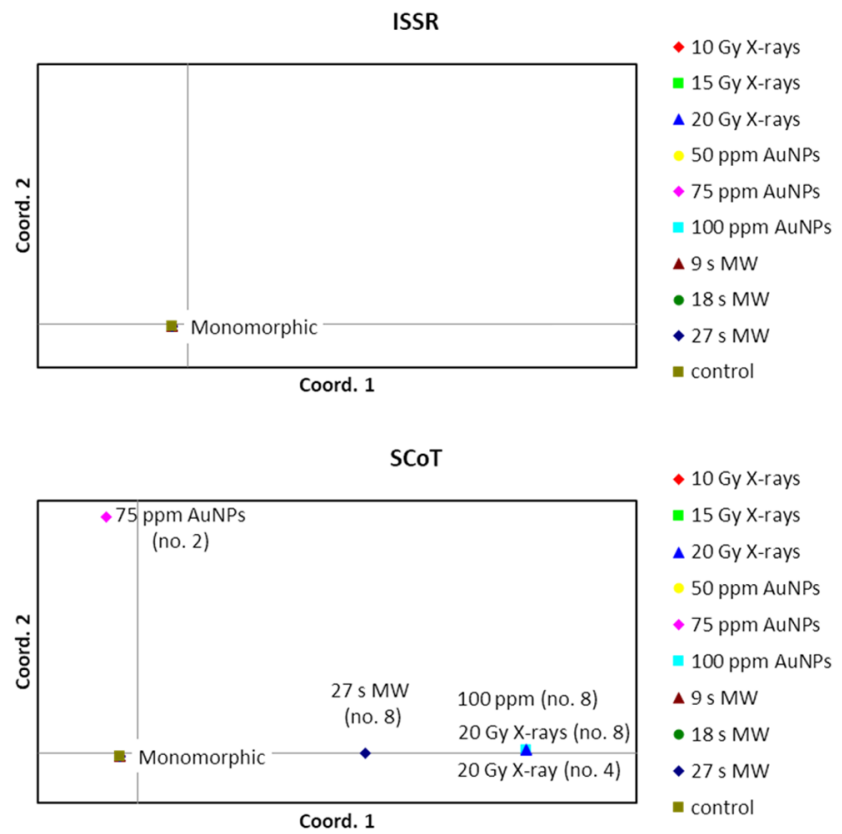

Repeat (ISSR), Randomly Amplified Polymorphic DNA (RAPD), and Start Codon Target Polymorphism (SCoT) markers

Table 9 Comparison of the effectiveness of various marker types in detecting variation in L. spectabilis 'Valentine' treated with chemical or physical agents

\begin{tabular}{|c|c|c|c|c|c|c|c|}
\hline \multirow{2}{*}{$\begin{array}{l}\text { Mutant } \\
\text { no. }\end{array}$} & \multirow{2}{*}{ Treatment } & \multirow{2}{*}{ FCM } & \multicolumn{4}{|c|}{ SPAR markers } & \multirow{2}{*}{$\begin{array}{c}\text { Phenotype } \\
\text { analysis }\end{array}$} \\
\hline & & & ISSR & DAMD & RAPD & SCoT & \\
\hline M1 & $50 \mathrm{ppm}$ AuNPs & + & - & - & - & - & - \\
\hline M2 & 75 ppm AuNPs & - & - & + & + & + & + \\
\hline M3 & 100 ppm AuNPs & - & - & + & + & + & - \\
\hline M4 & $27 \mathrm{~s} \mathrm{MW}$ & + & - & + & - & + & - \\
\hline M5 & 10 Gy X-rays & + & - & - & - & - & + \\
\hline M6 & 10 Gy X-rays & + & - & - & - & - & + \\
\hline M7 & 15 Gy X-rays & - & - & + & - & - & - \\
\hline M8 & 20 Gy X-rays & + & - & + & + & + & + \\
\hline M9 & 20 Gy X-rays & - & - & + & + & + & - \\
\hline
\end{tabular}

FCM flow cytometry, DAMD directed amplification of minisatellite DNA, ISSR inter sequence simple repeat, RAPD randomly amplified polymorphic DNA, SCOT start codon target polymorphism, SPAR single primer amplification reaction, “+" variation detected, "-" variation not detected

of secondary metabolites, and breeding possibilities in ornamental and medicinal plant species. This is the first study on the application of nanoparticles and ionizing radiation in micropropagation and mutation induction in bleeding heart. The results of the current experiment have broadened the scope of knowledge about the biology and requirements of $L$. spectabilis, which is a rather difficult plant species to be grown in the in vitro environment (VITROFLORA, Trzęsacz, Poland, personal communication).

\section{In vitro development and acclimatization efficiency of bleeding heart exposed to AuNPs and electromagnetic irradiation}

The present study highlights the utility of gold nanoparticles in micropropagation of bleeding heart 'Valentine'. The addition of AuNPs into the culture medium, regardless of their concentration, stimulated the proliferation of shoots and nearly tripled the propagation ratio (at $75 \mathrm{ppm}$ ) 
compared to the non-treated control. Moreover, AuNPs at the highest $100 \mathrm{ppm}$ concentration enhanced the elongation and branching of roots during the rooting stage. This is of significant importance for the whole of plant life as roots provide and transport water and minerals to the upper organs that permit successful photosynthetic nutrition (Dubrovsky et al. 2019). Similarly to our findings, the best effects in the in vitro stimulation of the rosulate and phyllomorphs regeneration in Streptocarpus $\times$ hybridus Voss. were reported if silver or gold nanoparticles ( $20 \mathrm{~nm}$ in size) were added to the MS medium but at a much lower concentration of $10 \mathrm{ppm}$ (Tymoszuk and Miler 2019). According to Tian et al. (2018), the application of 25 ppm of manganese nanoparticles $(30 \mathrm{~nm})$ can result in pores formation in the roots stimulating a greater uptake of water and nutrients and, consequently, in significant plant growth. Allium cepa $\mathrm{L}$. root tip cells treated with AuNPs exhibited an increment in the frequency of mitotic index with the increase in nanoparticles concentration from 10 to $1000 \mathrm{ppm}$ (Gopinath et al. 2013). Moreover, nanoparticles can additionally alter the absorption of metal ions important for plant development (Timoteo et al. 2019) or stimulate a more intensive lignin accumulation in cell walls improving the quality of in vitro propagated plants (Bernard et al. 2015). These mechanisms of NPs action could explain the present results and the activation of axillary meristems in bleeding heart. Nonetheless, less beneficial effects of various types of nanoparticles in other plant species are also known, such as inhibition of seed germination and/or seedling development (Sanzari et al. 2019). Further studies should focus on the effect of NPs size on the micropropagation efficiency in bleeding heart.

In the current study, the foliar analysis revealed that treatment with X-rays, especially with 15 and $20 \mathrm{~Gy}$, increased the fresh and dry weight of shoots without altering their relative water content. Those plants were also of the highest viability when transferred to ex vitro conditions $(100 \%$ survival). This positive effect of X-rays could be related to the so-called hormesis, i.e. a favorable response of plants to low-level exposures to adverse conditions (Jalal et al. 2021). Conversely, this type of treatment negatively affected the spontaneous rooting capability (24.0-41.4\% vs $80.0 \%$ in the control) and root parameters (length, area, and volume) in L. spectabilis. A similar phenomenon was observed in Vicia faba $\mathrm{L}$., in which studies have shown that X-ray radiation can have a destructive influence on auxins, responsible for rooting, and affects meristematic cells (Blaser et al. 2018).

Transfer to ex vitro conditions is a neuralgic step in every micropropagation protocol. A significant decline in plants survival due to in vitro-induced anatomical and physiological disorders is often reported (Bidabadi and Jain 2020). In the present study, the hormesis phenomenon could also explain the higher acclimatization effectiveness and better quality of plants from most experimental objects than in the non-treated control. Only after the longest MW-treatment (27 s), a decline in the ex-vitro survival was observed. This could be due to the effect of dielectric heating (Diprose 2001). When the electromagnetic MW radiation from oscillating electric fields is absorbed by tissues, it provokes a rotation of water molecules that leads to heating (Khalafallah and Sallam 2009). This increase in temperature can lead to the damage of cells (Diprose 2001), evident during the critical acclimatization stage and ex vitro growth when the plant is exposed to considerable stress. On the other hand, no negative impact of AuNPs on the acclimatization efficiency highlights the usefulness of these nanoparticles in the reproduction of bleeding heart.

\section{Physiological and biochemical response of bleeding heart to in vitro-induced stress}

The present research confirmed that AuNPs, MW, and X-rays are a source of considerable oxidative stress in plants if applied at high doses. This was evident based on the activity analysis of the three enzymes studied, which was elevated up to five times as in the case of G-POD after applying $20 \mathrm{~Gy}$ of X-rays. Our results are in agreement with several other studies related to the antioxidant defense system in higher plants (Barbasz et al. 2016; Chandel et al. 2017). Nanoparticles and electromagnetic radiation have various chemical effects, including causing deterioration in large molecules in cells and imbalance in ionic equilibrium leading to generation of hazardous by-products, known as reactive oxygen species (ROS), during biological reactions (Dietz and Herth 2011; Kivrak et al. 2017). In the present study, guaiacol peroxidase was the most sensitive marker of oxidative stress, while glutathione reductase - the least (a twofold activity increase reported solely in the experimental object with the highest concentration of AuNPs). These findings corroborate our previous report on the impact of cryopreservation stress on the physiological response in L. spectabilis (Kulus and Tymoszuk 2021). On the other hand, the antioxidant enzymatic activity did not change significantly if the studied factors were used at lower doses, which is especially important for AuNPs application in micropropagation.

It was also found that both chemical and physical agents can be used to alternate the profile of metabolites in bleeding heart. Spectral fingerprinting revealed modulation of plant pigments; a significant, nearly two-fold increase in the concentrations of chlorophylls and carotenoids were found if microwaves were used for a total of $18 \mathrm{~s}$. Other changes were also found that lead to the plantlets color change during the in vitro growth stage. According to Kumar et al. (2018), plants produce a number of secondary metabolites such as flavonoids, phenolics, terpenoids, amino acids and increase the level of different enzymes to reduce the effect of ROS, which is the probable reason for those changes. It is worth 
mentioning that all experimental objects contained more polyphenols (TPC) than the control and, often also, a higher concentration of tannins, which is of significant importance for the pharmaceutical industry. Gold nanoparticles in particular affected the content of tannins, which additionally highlights the utility of NPs in plant biotechnology and abiotic elicitation (Halder et al. 2019).

\section{Genome size and genetic stability analyses in bleeding heart}

Currently, the genome size (i.e. the total amount of DNA contained in the cell nucleus) is estimated in over 12,000 plant species (Pellicer and Leitch 2020). This parameter can have an impact at many scales, from influencing gene and genome dynamics to playing a role at the whole-plant level, influencing, for example, plant growth strategies (Dodsworth et al. 2015; Guignard et al. 2016). The obtained results revealed that bleeding heart has a very small genome size of approximately $1281 \mathrm{Mbp}(2 \mathrm{C} \mathrm{DNA}=1.314 \mathrm{pg})$, according to the classification of angiosperms by Soltis et al. (2003). In comparison, the lowest known value of this parameter in Genlisea tuberosa Rivadavia (Lentibulariaceae) was 61 $\mathrm{Mbp} / 1 \mathrm{C}$, and the largest in Paris japonica (Franch. \& Sav.) Franch (Liliaceae) reached 149,000 Mbp/1C of DNA (Pellicer et al. 2018). A plant species of such a small genome may be a good model organism in experimental biology, for example in the studies related to understanding evolutionary trajectories and ecosystem dynamics.

In the present study, a total of five plants (3.3\%) had a changed DNA content, mainly after irradiation with X-rays (three plants). Most of the altered bleeding hearts (80\%) had a lower nuclear DNA concentration than the remaining plants from the same experimental combination. This suggests that the applied mutagens caused considerable deletions from the genome of the original 'Valentine' cultivar. This also may be a result of stress, which negatively affects the synthesis of DNA, as reported in other plant species (Oladosu et al. 2016). A similar negative effect of ionizing irradiation on DNA content in chrysanthemum was reported previously by Miler et al. (2020). In bleeding heart, only in a single sample, treated with $10 \mathrm{~Gy} \mathrm{X}$-rays, an increase in genome size was found.

Since some genetic alternations can be eliminated due to the so-called diplontic selection and mutational meltdown (Klekowski 2003), the genetic (PCR) analysis of plants was performed after 6 weeks of ex vitro growth. The SPAR markers detected mutations in six of the analyzed plants (7.5\%). Electromagnetic/ionizing radiation is well known for its mutagenic character and is broadly used in classical mutation breeding (Miler and Kulus 2018; Miler et al. 2021). Nanoparticles also can penetrate cells and impair stages of mitosis causing chromatin bridges and stickiness, disturbed metaphase, multiple chromosomal breaks, and cell disintegration (Kumari et al. 2009). To date, the mutagenic character of zinc oxide nanoparticles (ZnONPs) and AgNPs was confirmed by Kumari et al. (2011) in onion and by Tymoszuk and Kulus (2020) in chrysanthemum, respectively. The present study confirmed also the genotoxic effect of AuNPs if applied at high concentrations. Based on the frequency of variation occurrence in $L$. spectabilis, the usefulness of the three studied factors in breeding can be arranged as follows: MW $<$ AuNPs $<$ X-rays.

In the present study, only in a single plant (M8; X-ray treated), all three marker types (FCM, SPAR, and phenotype analysis) detected variation, while in the mutant M2 (AuNPs-treated) changes in the DNA sequence and plant morphology were evident. Lack of noticeable variation in the DNA content in the latter plant could result from the small size of the mutation, as most of the DNA sequence alternations between alleles in plants are limited to single nucleotides (Morgil et al. 2020). On the other hand, in the mutant M1, only FCM detected a significant change in the nuclear DNA amount. As for this plant, the variation could have occurred in the part of the genome, which is not covered by SPAR markers (Nadeem et al. 2017). The same explanation goes for mutants M5 and M6 (Table 9). In the remaining four mutants, genetic and/or cytogenetic markers detected variation despite no phenotype changes. This may suggest that the DNA was altered in the non-coding regions of the genome; the so-called gene deserts or 'junk DNA' (Nadeem et al. 2017). All of the phenotype alternations reported in the present study considered changes in the shape and symmetry of leaves. This is one of the most common changes occurring as a result of mutation induction (Masters 1869), important in bleeding heart as the species is also valued for its distinctive foliage with cut merit (Hodges 2012). Forthcoming analyses will be aimed at analyzing the parameters of flowers in blooming plants.

The present research confirmed the diverse usefulness of various PCR-based marker systems in the detection of polymorphisms in bleeding heart. Among the four marker systems tested, only ISSR failed to detect polymorphic bands. Moreover, this was the only marker where not all of the used primers generated amplicons. Similarly, in Vitis vinifera L., ten ISSR primers were evaluated, but only two were capable to amplify distinct and reproducible bands with sizes between 300 and 2000 bp (Lazo Javalera et al. 2016). The discriminating power of the studied markers could be arranged in the following order: ISRR $<$ SCOT $<$ RAPD $<$ DAMD. DAMDs distinguished the highest number of polymorphic plants, although the PCR reaction for those markers was the most difficult to optimize (data not shown). The high efficiency of RAPDs was also confirmed in members of the Asteraceae botanical family by Lema-Rumińska et al. (2019). 
In future studies, other cultivars of bleeding heart should be tested to obtain the widest possible variability, as it is known that the genetic factor has a significant impact on the efficiency and range of spontaneous and induced mutations occurrence. For example, in chrysanthemum, cultivars with purple inflorescences mutate most often, while the least frequent variation occurs in plants with yellow flowers (Schum 2003). For this reason, also in the present study, a red-floral 'Valentine' cultivar was used, but the purple-pink L. spectabilis 'Gold Heart' could also provide some interesting results.

It is also worth mentioning that in the present study, none of the experimental objects differed significantly from the control in terms of viability during the in vitro cultivation (86-100\%). For nodal segments of Citrus macrophylla Wester., the $\mathrm{LD}_{50}$ was determined as $29.2 \mathrm{~Gy}$ of $\gamma$-rays (Tallón et al. 2015). This underlines the high tolerance of bleeding heart to stress conditions. It is, therefore, possible that this species could be a source of resistance genes in hybridization programs. In future studies with bleeding heart, an even higher dose of the tested factors could be used to increase the number of mutated plants and traits and to determine the $\mathrm{LD}_{50}$ in this species.

\section{Conclusions}

The addition of AuNPs into the culture medium, especially at $75 \mathrm{ppm}$, provokes the proliferation of shoots and multiplication ratio in Lamprocapnos spectabilis 'Valentine'. Gold nanoparticles also stimulate the elongation and branching of roots. On the other hand, irradiation of explants with $\mathrm{X}$-rays results in the development of leaves with the highest fresh and dry weight but inhibits the rooting of shoots. Gold nanoparticles and electromagnetic irradiation affect also the profile of metabolites in bleeding heart and improve the survival and quality of acclimatized plants. Both chemical and physical agents applied at high doses can be a source of genetic variation, with X-rays and MW being the most and the least effective mutagens, respectively. DAMD and RAPD markers are the most suitable for mutation detection. The induced biochemical and genetic alternations can result in phenotype change in L. spectabilis leading to the creation of new cultivars. The simple propagation and breeding layouts could be easily implemented in commercial and research laboratories with possible extensions to other cultivars or species.

Future studies should focus on the usage of other agents; such as gamma rays, fast neutrons (FN), or AgNPs, applied at even higher doses than in the current study, in mutagenesis of bleeding heart. Various cultivars should be compared to screen for traits indicating higher susceptibility to mutation occurrence. A broad analysis of phenotype alterations should be performed in the in vivo-grown plants to confirm their stability in the subsequent generations.

Acknowledgements The authors wish to thank Agnieszka Łojko, Bydgoszcz University of Science and Technology, Poland for technical support in performing the FCM analyses.

Author contributions DK: Conceptualization. DK, AT, IJ: Data curation. DK, AT, IJ: Formal analysis. DK, AT, IJ: Investigation. DK, AT, IJ, JW: Methodology. DK: Project administration. DK, AT, IJ, JW: Resources. DK: Supervision. DK: Validation. DK: Visualization. DK: Writing-original draft preparation. DK, AT, IJ, JW: Writing-review and editing. All authors have read and agreed to the published version of the manuscript.

Funding This research did not receive any specific grant from funding agencies in the public, commercial, or not-for-profit sectors.

Data availability Data available by e-mail on reasonable request.

Code availability Not applicable.

\section{Declarations}

Conflict of interest The authors declare no commercial or financial conflict of interest.

Open Access This article is licensed under a Creative Commons Attribution 4.0 International License, which permits use, sharing, adaptation, distribution and reproduction in any medium or format, as long as you give appropriate credit to the original author(s) and the source, provide a link to the Creative Commons licence, and indicate if changes were made. The images or other third party material in this article are included in the article's Creative Commons licence, unless indicated otherwise in a credit line to the material. If material is not included in the article's Creative Commons licence and your intended use is not permitted by statutory regulation or exceeds the permitted use, you will need to obtain permission directly from the copyright holder. To view a copy of this licence, visit http://creativecommons.org/licenses/by/4.0/.

\section{References}

Adamski Z, Blythe LL, Milella L, Bufo SA (2020) Biological activities of alkaloids: from toxicology to pharmacology. Toxins 12(4):210. https://doi.org/10.3390/toxins12040210

Adhikari S, Biswas A, Saha S, Biswas A, Ghosh P (2020) SPAR methods reveal high genetic diversity within populations and moderate gene flow of pointed gourd (Trichosanthes dioica Roxb.) germplasm. Biocat Agric Biotechnol 29:101760. https://doi.org/10. 1016/j.bcab.2020.101760

Amiryousefi A, Hyvönen J, Poczai P (2018) iMEC: online marker efficiency calculator. Appl Plant Sci 6(6):e1159. https://doi.org/10. 1002/aps3.1159

Barbasz A, Kreczmer B, Oćwieja M (2016) Effects of exposure of callus cells of two wheat varieties to silver nanoparticles and silver salt $\left(\mathrm{AgNO}_{3}\right)$. Acta Physiol Plant 38:76. https://doi.org/10.1007/ s11738-016-2092-Z

Bernard F, Moghadam NN, Mirzahani F (2015) The effect of colloidal silver nanoparticles on the level of lignification and hyperhydricity syndrome in Thymus deanensis vitro shoots: a possibile 
involvement of bonded polyamines. In Vitro Cell Dev Biol-Plant 51:546-553. https://doi.org/10.1007/s11627-015-9700-2

Bidabadi SS, Jain SM (2020) Cellular, molecular, and physiological aspects of in vitro plant regeneration. Plants 9(6):702. https://doi. org/10.3390/plants9060702

Blaser SRGA, Schlüter S, Vetterlein D (2018) How much is too much? Influence of X-ray dose on root growth of faba bean (Vicia faba) and barley (Hordeum vulgare). PLoS ONE 13(3):e0193669. https://doi.org/10.1371/journal.pone.0193669

Bradford MM (1976) A rapid and sensitive method for the quantitation of microgram quantities of protein utilizing the principle of protein-dye binding. Anal Biochem 72:248-254. https://doi.org/ 10.1016/0003-2697(76)90527-3

Brighente I, Dias M, Verdi G, Pizzolatti G (2008) Antioxidant activity and total phenolic content of some Brazilian species. Pharm Biol 45(2):156-161. https://doi.org/10.1080/13880200601113131

Bulda OV, Rassadina VV, Alekseichuk HN, Laman NA (2008) Spectrophotometric measurement of carotenes, xanthophylls, and chlorophylls in extracts from plant seeds. Russ J Plant Physiol 55:544. https://doi.org/10.1134/S1021443708040171

Chandel S, Kaur S, Singh HP, Batish DR, Kohli RK (2017) Exposure to $2100 \mathrm{MHz}$ electromagnetic field radiations induces reactive oxygen species generation in Allium cepa roots. J Microsc Ultrastruct 5(4):225-229. https://doi.org/10.1016/j.jmau.2017.09.001

Cho JS (2018) Effect of gibberellic acid on embryo development and germination of Dicentra spectabilis (L.) Lem. seeds. In: Proc Plant Res Soc Korea Conf, p 60

Cho JS, Jang BK, Lee SM, Lee IJ, Lee CH (2020) Factors affecting the dormancy and germination of bleeding heart [Lamprocapnos spectabilis (L.) Fukuhara] seeds. Plant Biol 22:514-521

Collard BCY, Mackill DJ (2009) Start codon targeted (SCoT) polymorphism: a simple, novel DNA marker technique for generating gene-targeted markers in plants. Plant Mol Biol Rep 27:86-93. https://doi.org/10.1007/s11105-008-0060-5

Dastborhan S, Ghassemi-Golezani K (2015) Influence of seed priming and water stress on selected physiological traits of borage. Folia Hortic 27(2):151-159. https://doi.org/10.1515/fhort-2015-0025

Datta SK (2020) Induced mutations: Technological advancement for development of new ornamental varieties. Nucleus 63:119-129. https://doi.org/10.1007/s13237-020-00310-7

Deno NC (1993) Seed germination theory and practice, 2nd edn. Pennsylvania State College, Pennsylvania, p 53

Dietz KJ, Herth S (2011) Plant nanotoxicology. Trends Plant Sci 16(1):582-589. https://doi.org/10.1016/j.tplants.2011.08.003

Diprose MF (2001) Some considerations when using a microwave oven as a laboratory research tool. Plant Soil 229:271-280

Dodsworth S, Leitch AR, Leitch IJ (2015) Genome size diversity in angiosperms and its influence on gene space. Curr Op Genet Dev 35:73-78. https://doi.org/10.1016/j.gde.2015.10.006

Doležel J, Sgorbati S, Lucretti S (1992) Comparison of three DNA fluorochromes for flow cytometric estimation of nuclear DNA content in plants. Physiol Plant 85:625-631. https://doi.org/10. 1111/j.1399-3054.1992.tb04764.x

Doležel J, Bartoš J, Voglmayr H, Greilhuber J (2003) Nuclear DNA content and genome size of trout and human. Cytometry 51A:127-128. https://doi.org/10.1002/cyto.a.10013

Dubrovsky JG, Fukaki H, Laplaze L, Laskowski M (2019) Root branching: From lateral root primordium initiation and morphogenesis to function. Front Plant Sci 10:1462. https://doi.org/10. 3389/fpls.2019.01462

Gopinath K, Venkatesh KS, Ilangovan R, Sankaranarayanan K, Arumugam A (2013) Green synthesis of gold nanoparticles from leaf extract of Terminalia arjuna, for the enhanced mitotic cell division and pollen germination activity. Ind Crops Prod 50:737-742. https://doi.org/10.1016/j.indcrop.2013.08.060
Guignard MS, Nichols RA, Knell RJ, Macdonald A, Romila C-A, Trimmer M, Leitch IJ, Leitch AR (2016) Genome size and ploidy influence angiosperm species' biomass under nitrogen and phosphorus limitation. New Phytol 210(4):1195-1206. https://doi.org/ 10.1111/nph.13881

Halder M, Sarkar S, Jha S (2019) Elicitation: A biotechnological tool for enhanced production of secondary metabolites in hairy root cultures. Eng Life Sci 19:880-895. https://doi.org/10.1002/elsc. 201900058

Harborne JB (1967) Comparative biochemistry of the flavonoids. Phytochemistry 6(11):1569-1573. https://doi.org/10.1016/S00319422(00)82952-0

Heath DD, Iwana GK, Delvin RH (1993) PCR primed with VNTR core sequences yields species specific patterns and hypervariable probes. Nucl Acid Res 21:5782-5785. https://doi.org/10.1093/ nar/21.24.5782

Hodges L (2012) Bleeding heart: a review for growers. Hortic Technol 22(4):517-522. https://doi.org/10.21273/HORTTECH.22.4.517

Holme IB, Gregersen PL, Brinch-Pedersen H (2019) Induced genetic variation in crop plants by random or targeted mutagenesis: convergence and differences. Front Plant Sci 10:1468. https://doi.org/ 10.3389/fpls.2019.01468

Homaee MB, Ehsanpour AA (2016) Silver nanoparticles and silver ions: oxidative stress responses and toxicity in potato (Solanum tuberosum L.) grown in vitro. Hortic Environ Biotechnol 57(6):544-553. https://doi.org/10.1007/s13580-016-0083-z

Jalal A, de Oliveira JC, Ribeiro JS, Fernandez GC, Mariano GG, Trindade VDR, Dos Reis AR (2021) Hormesis in plants. Physiological and biochemical responses. Ecotoxicol Environ Saf 207:111225. https://doi.org/10.1016/j.ecoenv.2020.111225

Jo YD, Kim J-B (2019) Frequency and spectrum of radiation-induced mutations revealed by whole-genome sequencing analyses of plants. Quantum Beam Sci 3:7. https://doi.org/10.3390/qubs3 020007

Kabir MSH, Hossain MM, Kabir I, Rahman M, Hasanat A, Emran TB, Rahman A (2016) Phytochemical screening, antioxidant, thrombolytic, $\alpha$-amylase inhibition and cytotoxic activities of ethanol extract of Steudnera colocasiifolia K. Koch Leaves. J Young Pharm 8(4):391-397. https://doi.org/10.5530/jyp.2016.4.15

Kamińska M, Śliwa H, Rudzińska-Langwald A (2004) First report of shoot proliferation of bleeding heart (Dicentra spectabilis) in Poland, associated with phytoplasma infection. Plant Pathol 53(6):81. https://doi.org/10.1111/j.1365-3059.2004.01086.x

Khalafallah AA, Sallam SM (2009) Response of maize seedlings to microwaves at 945 MHZ. Romanian J Biophys 19(1):49-62

Kivrak EG, Yurt KK, Kaplan AA, Alkan I, Altun G (2017) Effects of electromagnetic fields exposure on the antioxidant defense system. J Microsc Ultrastruct 5(4):167-176. https://doi.org/10.1016/j. jmau.2017.07.003

Klekowski EJ (2003) Plant clonality, mutation, diplontic selection and mutational meltdown. Biol J 79(1):61-67. https://doi.org/10. 1046/j.1095-8312.2003.00183.x

Kulus D (2020) Shoot tip cryopreservation of Lamprocapnos spectabilis (L.) Fukuhara using different approaches and evaluation of stability on the molecular, biochemical, and plant architecture levels. Int J Mol Sci 21:3901. https://doi.org/10.3390/ijms21113901

Kulus D, Tymoszuk A (2020) Induction of callogenesis, organogenesis, and embryogenesis in non-meristematic explants of bleeding heart and evaluation of chemical diversity of key metabolites from callus. Int J Mol Sci 21:5826. https://doi.org/10.3390/ijms21165826

Kulus D, Tymoszuk A (2021) Gold nanoparticles affect the cryopreservation efficiency of in vitro-derived shoot tips of bleeding heart. Plant Cell Tissue Organ Cult 146:297-311. https://doi.org/10. 1007/s11240-021-02069-4

Kulus D, Muhire JD, Aksoy B (2020) Growth regulation and validation of homogeneity in in vitro-derived bleeding heart by molecular 
markers and spectral analysis of pigments. J Plant Growth Regul 40:1521-1538. https://doi.org/10.1007/s00344-020-10204-2

Kumar V, Singh S, Singh A, Dixit AK, Shrivastava B, Kondalkar SA, Singh RP, Subhose V, Prakash O (2018) Detremination of phytochemical, antioxidant, antimicrobial and protein binding qualities of hydroethanolic extract of Celastrus paniculatus. J Appl Biol Biotechnol 6:11-17. https://doi.org/10.7324/JABB.2018.60602

Kumari M, Mukherjee A, Chandrasekaran N (2009) Genotoxicity of silver nanoparticles in Allium cepa. Sci Total Environ 407:52435246. https://doi.org/10.1016/j.scitotenv.2009.06.024

Kumari M, Khan SS, Pakrashi S, Mukherjee A, Chandrasekaran N (2011) Cytogenetic and genotoxic effect of zink oxide nanoparticles on root cells of Allium cepa. J Hazard Mater 90:613-621. https://doi.org/10.1016/j.jhazmat.2011.03.095

Lazo Javalera MF, Tiznado Hernández ME, Vargas Arispuro I, Martínez Téllez MÁ, Islas Osuna MA, Hernández Oñate MÁ, Rivera Domínguez M (2016) Genetic stability of cryopreserved grapevine (Vitis vinifera L.) genome by vitrification method. J Agric Sci Technol B 6:380-386. https://doi.org/10.17265/2161-6264/ 2016.06.003

Lee KP, Lee DW (2003) Somatic embryogenesis and plant regeneration from seeds of wild Dicentra spectabilis (L.) Lem. Plant Cell Rep 22:105-109. https://doi.org/10.1007/s00299-003-0642-5

Lema-Rumińska J, Miler N, Gęsiński K (2018) Identification of new Polish lines of Chenopodium quinoa (Willd.) by spectral analysis of pigments and a confirmation of genetic stability with SCoT and RAPD markers. Acta Sci Pol Hortic Cult 17(1):75-86. https://doi. org/10.24326/asphc.2018.1.7

Lema-Rumińska J, Kulus D, Tymoszuk A, Varejão JMTB, Bahcevandziev K (2019) Profile of secondary metabolites and genetic stability analysis in new lines of Echinacea purpurea (L.) Moench micropropagated via somatic embryogenesis. Ind Crops Prod 142:111851. https://doi.org/10.1016/j.indcrop.2019.111851

Maehly AC, Chance B (1954) The assay of catalases and peroxidases. In: Glick D (ed) Methods of biochemical analysis. Willey, New York, pp 357-425. https://doi.org/10.1002/9780470110171.ch14

Mallebrera B, Font G, Ruiz MJ (2014) Disturbance of antioxidant capacity produced by beauvericin in CHO-K1 cells. Toxicol Lett 226:337-342. https://doi.org/10.1016/j.toxlet.2014.02.023

Manokari M, Priyadharshini S, Jogam P, Dey A, Shekhawat MS (2021) Meta-topolin and liquid medium mediated enhanced micropropagation via ex vitro rooting in Vanilla planifolia Jacks. ex Andrews. Plant Cell Tissue Organ Cult. https://doi.org/10.1007/ s11240-021-02044-Z

Masters MT (1869) Vegetable teratology: an account of the principal deviations from the usual construction of plants. The Ray Society, London, pp 1-7

Miler N, Kulus D (2018) Microwave treatment can induce chrysanthemum phenotypic and genetic changes. Sci Hortic 227(3):223-233. https://doi.org/10.1016/j.scienta.2017.09.047

Miler N, Kulus D, Sliwinska E (2020) Nuclear DNA content as an indicator of inflorescence colour stability of in vitro propagated solid and chimera mutants of chrysanthemum. Plant Cell Tissue Organ Cult 143:421-430. https://doi.org/10.1007/s11240-020-01929-9

Miler N, Jedrzejczyk I, Jakubowski S, Winiecki J (2021) Ovaries of chrysanthemum irradiated with high-energy photons and highenergy electrons can regenerate plants with novel traits. Agronomy 11(6):1111. https://doi.org/10.3390/agronomy11061111

Morgil H, Gercek YC, Tulum I (2020) Single nucleotide polymorphisms (SNPs) in plant genetics and breeding. In: Çalışkan M et al. (eds) The recent topics in genetic polymorphisms, InTechOpen. https://doi.org/10.5772/intechopen.91886

Murashige T, Skoog F (1962) A revised medium for rapid growth and bio assays with tobacco tissue cultures. Physiol Plant 15:473-497. https://doi.org/10.1111/j.1399-3054.1962.tb08052.x
Nadeem MA, Nawaz MA, Shahid MQ, Dogan Y, Comertpay G, Yildiz M, Hatipoglu R, Ahmad F, Alsaleh A, Labhane N, Ozkan H, Chung G, Baloch FS (2017) DNA molecular markers in plant breeding: current status and recent advancements in genomic selection and genome editing. Biotechnol Biotechnol Equip 32(2):261-285. https://doi.org/10.1080/13102818.2017.1400401

Nakano Y, Asada K (1981) Hydrogen peroxide is scavenged by ascorbate specific peroxidase in spinach chloroplasts. Plant Cell Physiol 22:867-880. https://doi.org/10.1093/oxfordjournals.pcp.a076232

Nowogórska A, Patykowski J (2015) Selected reactive oxygen species and antioxidany enzymes in common bean after Pseudomonas syringae pv. phaseolicola and Botrytis cinerea infection. Acta Physiol Plant 37:1725. https://doi.org/10.1007/ s11738-014-1725-3

Och A, Szewczyk K, Pecio Ł, Stochmal A, Załuski D (2017) UPLCMS/MS profile of alkaloids with cytotoxic properties of selected medicinal plants of the Berberidaceae and Papaveraceae families. Oxid Med Cell Longevity. https://doi.org/10.1155/2017/9369872

Oladosu Y, Rafii MY, Abdullah N, Hussin G, Ramli A, Rahim HA, Miah G, Usman MG (2016) Principle and application of plant mutagenesis in crop improvement: a review. Biotechnol Biotechnol Equip 30:1-16. https://doi.org/10.1080/13102818.2015.10873 33

Park S, An B, Par SJ (2018) Reconfiguration of the plastid genome in Lamprocapnos spectabilis: IR boundary shifting, inversion, and intraspecific variation. Sci Rep 8:13568. https://doi.org/10.1038/ s41598-018-31938-w

Peakall R, Smouse PE (2012) GenAlEx 6.5: genetic analysis in Excel. Population genetic software for teaching and research-an update. Bioinformatics 28(19):2537-2539. https://doi.org/10.1093/bioin formatics/bts 460

Pellicer J, Leitch IJ (2020) The Plant DNA C-values database (release 7.1): an updated online repository of plant genome size data for comparative studies. New Phytol 226:301-305. https://doi.org/ $10.1111 / \mathrm{nph} .16261$

Pellicer J, Hidalgo O, Dodsworth S, Leitch IJ (2018) Genome size diversity and its impact on the evolution of land plants. Genes 9(2):88. https://doi.org/10.3390/genes9020088

Petruczynik A, Plech T, Tuzimski T, Misiurek J, Kaproń B, Misiurek D, Szultka-Młyńska M, Buszewski B, Waksmundzka-Hajnos M (2019) Determination of selected isoquinoline alkaloids from Mahonia aquifolia; Meconopsis cambrica; Corydalis lutea; Dicentra spectabilis; Fumaria officinalis; Macleaya cordata extracts by HPLC-DAD and comparison of their cytotoxic activity. Toxins 11:575. https://doi.org/10.3390/toxins11100575

Pfosser M, Amon A, Lelley T, Heberle-Bors E (1995) Evaluation of sensitivity of flow cytometry in detecting aneuploidy in wheat using disomic and ditelosomic wheat-rye addition lines. Cytometry A 21(4):387-393

Rewers M, Drouin J, Kisiala A, Sliwinska E, Cholewa E (2012) In vitro regenerated wetland sedge Eriophorum vaginatum L. is genetically stable. Acta Physiol Plant 34:2197-2206. https://doi.org/10. 1007/s11738-012-1020-0

Rout GR, Jain SM (2020) Advances in tissue culture techniques for ornamental plant propagation. In: Reid M (ed) Achieving sustainable cultivation of ornamental plants. Burleigh Dodds Science Publishing, Cambridge, pp 1-39. https://doi.org/10.19103/AS. 2020.0066.04

Sanzari I, Leone A, Ambrosone A (2019) Nanotechnology in plant science: to make a long story short. Front Bioeng Biotechnol 7:120. https://doi.org/10.3389/fbioe.2019.00120

Schum A (2003) Mutation breeding in ornamentals: an efficient breeding method? Acta Hortic 612:47-60. https://doi.org/10.17660/ ActaHortic.2003.612.6 
Shelake RM, Pramanik D, Kim JY (2019) Evolution of plant mutagenesis tools: a shifting paradigm from random to targeted genome editing. Plant Biotechnol Rep 13:423-445. https://doi.org/10. 1007/s11816-019-00562-z

Sliwinska E (2018) Flow cytometry-a modern method for exploring genome size and nuclear DNA synthesis in horticultural and medicinal plant species. Folia Hortic 30(1):103-128. https://doi. org/10.2478/fhort-2018-0011

Soltis DE, Soltis PS, Bennett MD, Leitch IJ (2003) Evolution of genome size in the angiosperms. Am J Bot 90(11):1596-1603. https://doi.org/10.3732/ajb.90.11.1596

Tallón CI, Córdoba F, Porras I, Pérez-Tornero O (2015) Radiosensitivity of seeds and nodal segments of Citrus rootstocks irradiated in vitro with $\gamma$-rays from ${ }^{137} \mathrm{Cs}$. Acta Hortic 1065:549-555. https:// doi.org/10.17660/ActaHortic.2015.1065.69

Tian H, Ghorbanpour M, Kariman K (2018) Manganese oxide nanoparticle-induced changes in growth, redox reactions and elicitation of antioxidant metabolites in deadly nightshade (Atropa belladonna L.). Ind Crops Prod 126:403-414. https://doi.org/10.1016/j.inder op.2018.10.042

Timoteo C, Paiva R, dos Reis MV, Claro PIC, Ferraz LM, Marconcini JM, de Oliviera JE (2019) In vitro growth of Physalis peruviana L. affected by silver nanoparticles. 3 Biotech 9:145. https://doi. org/10.1007/s13205-019-1674-z

Tymoszuk A, Kulus D (2020) Silver nanoparticles induce genetic, biochemical, and phenotype variation in chrysanthemum. Plant
Cell Tissue Organ Cult 143:331-344. https://doi.org/10.1007/ s11240-020-01920-4

Tymoszuk A, Miler N (2019) Silver and gold nanoparticles impact on in vitro adventitious organogenesis in chrysanthemum, gerbera and Cape Primrose. Sci Hortic 257:108766. https://doi.org/10. 1016/j.scienta.2019.108766

Waterhouse AL (2001) Determination of total phenolics. In: Wrolstad RE (ed) Current protocols in food analytical chemistry. Wiley, New York, p I1.1.1-I1.1.8. https://doi.org/10.1002/0471142913. fai0101s06

Williams JGK, Kubelik AR, Livak KJ, Rafalski JA, Tingey SV (1990) DNA polymorphisms amplified by arbitrary primers are useful as genetic markers. Nucl Acids Res 18:6531-6535. https://doi.org/ 10.1093/nar/18.22.6531

Zietkiewicz E, Rafalski A, Labuda D (1994) Genome fingerprinting by simple sequence repeat (SSR)-anchored polymerase chain reaction amplification. Genome 20:176-183. https://doi.org/10.1006/ geno.1994.1151

Publisher's Note Springer Nature remains neutral with regard to jurisdictional claims in published maps and institutional affiliations. 